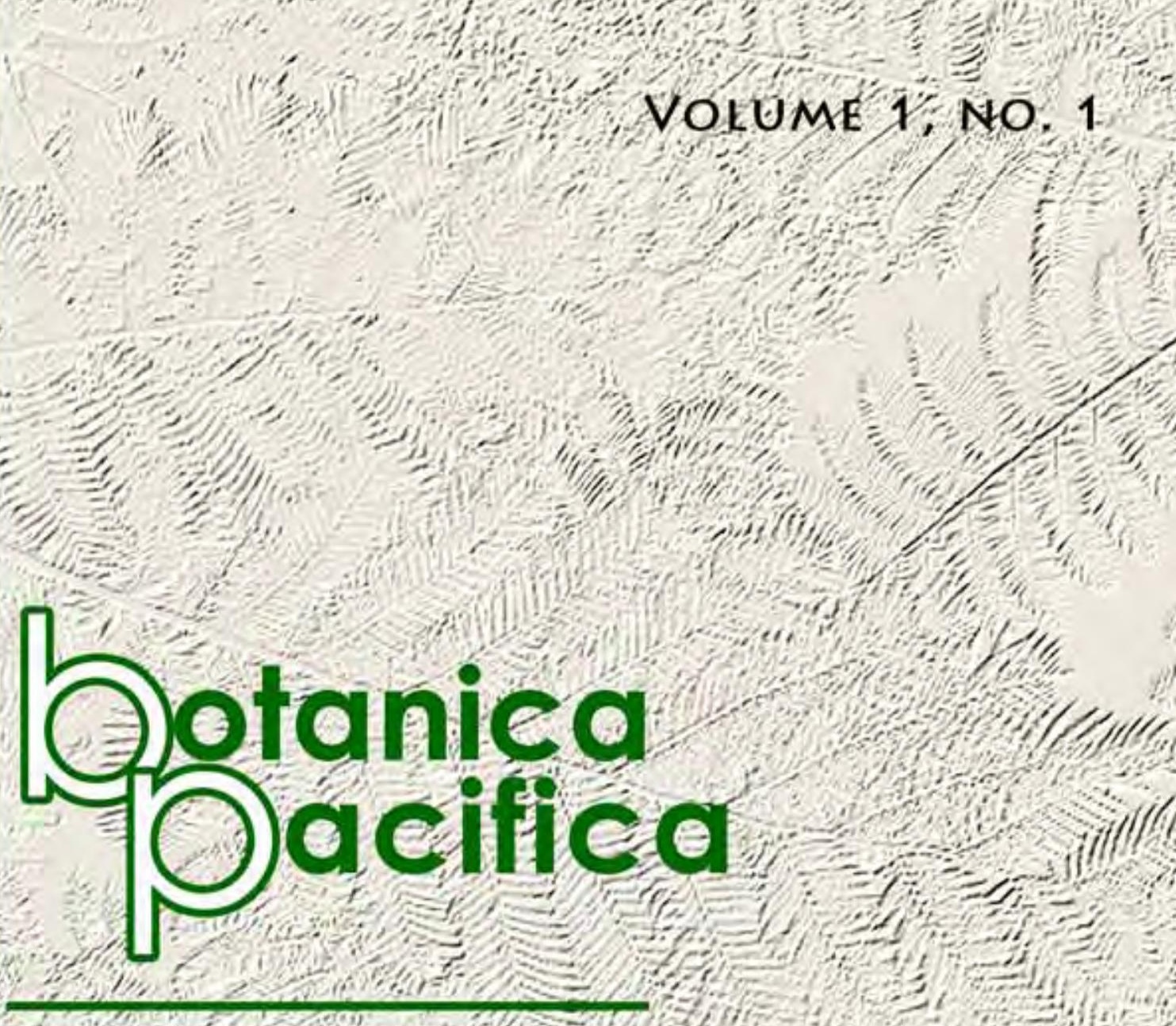

A journal of plant SCIENCE AND CONSERVATION

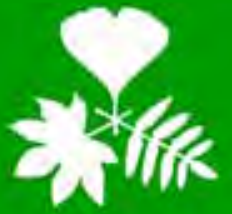

BOTANICAL GARDEN-INSTITUTE FEB RAS

*

INSTITUTE OF BIOLOGY AND

SOIL SCIENCE FEB RAS

WWW.CEOBOTANICA.RU/BP

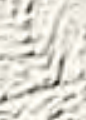

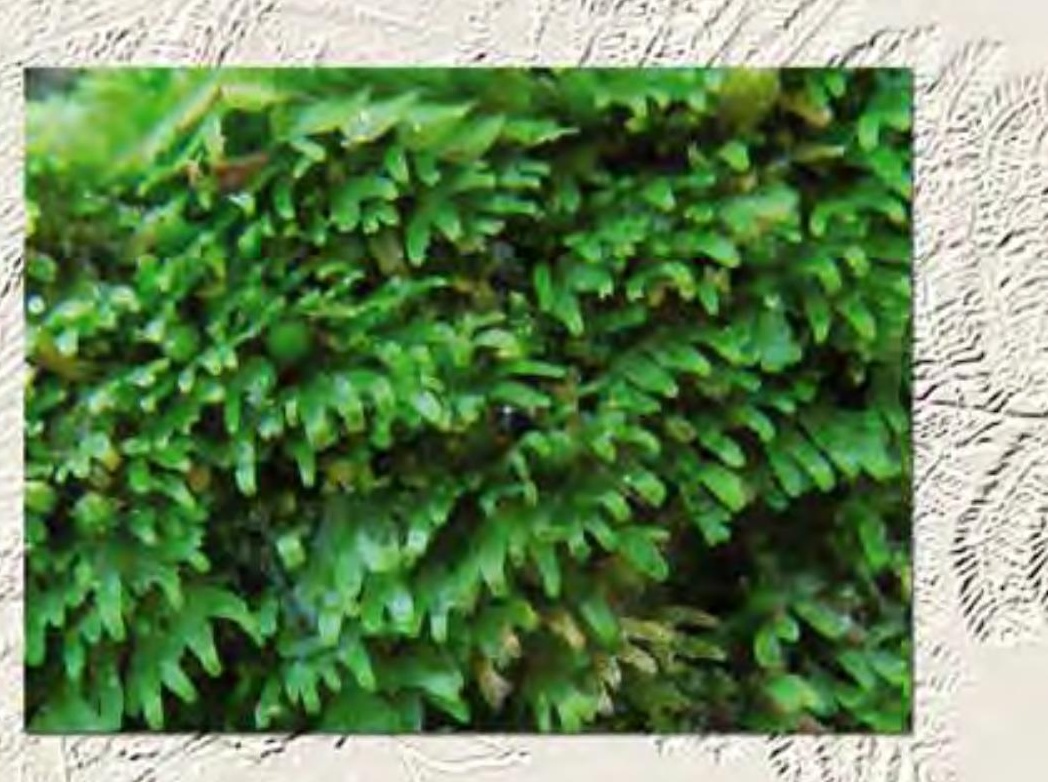




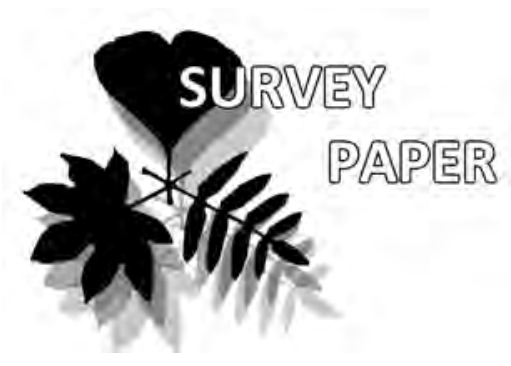

Elgene O. Box

${ }^{1}$ University of Georgia

Athens, Georgia, USA

E-mail: boxeo@uga.edu

Kazue Fujiwara

${ }^{2}$ Yokohama City University

Yokohama, Japan

E-mail: kazue@ynu.ac.jp

* Corresponding author

Manuscript received: 20.05.2012

Review completed: 30.06.2012

Accepted for publication: 15.07.2012

\section{A Comparative Look at Bioclimatic Zonation, Vegetation Types, Tree Taxa and Species Richness in Northeast Asia}

\author{
Elgene O. Box ${ }^{1 *} \&$ Kazue FujIIARA ${ }^{2}$
}

\begin{abstract}
A B S T R A C T
Northeast Asia includes the mainly temperate-deciduous and boreal forest areas of the Russian Far East, Manchuria, northern China, Korea, and northern Japan. In terms of global zonation, the region includes parts of the boreal, cool-temperate and typical-temperate zones, plus polar and the respective mountain belts. Zonation in Russia also recognizes sectoral subdivisions that represent the gradient from the ultra-continental interior to the maritime Pacific areas. Northeast Asia is compared herein with other regions of the Northern Hemisphere, within this zonal framework, in terms of bioclimatic conditions and zonation, vegetation types, main tree taxa, limiting mechanisms and ranges of taxa, and taxon richness. Northeast Asia has greater climatic extremes and climatic diversity, and species richness is generally seen as higher than in comparable areas of eastern North America and Europe. To some extent this results from the separation of Japan, Kamchatka, Sakhalin, and Korea from the East Asian mainland by the large marginal seas. Cool-temperate mixed forests seem strikingly similar in Northeast Asia and northeastern North America, although the extent of the former is truncated in some areas by the sudden appearance of permafrost. Some vegetation types of Northeast Asia are seen as more unique. Several research needs are identified by this cross-continental comparison, especially the need for more complete information on taxon ranges (including full range maps), a common zonation vocabulary, and better climate data. Consideration of the region as a whole also focuses attention on questions of just what really are different species and what factors limit them.
\end{abstract}

Keywords:

global bioclimatic zonation, temperate zonation, typical temperate climate, vegetation regions, East Asian species ranges, plant species richness

Бокс Э.О., ФуАзивара К. Сравнительный обзор биоклиматической зональности, типов растительности, Аревесных таксонов и видового богатства Северо-Восточной Азии

Северо-Восточная Азия включает умеренные широколиственно-лесные и бореальные районы Аальнего Востока России, Маньчжурии, северного Китая, Кореи и северной Японии. В схемах глобального районирования это части бореальной, холодно-умеренной и типичной умеренной зон, а также полярной зоны и соответствующих горных поясов. Российский подхоА к зонированию предусматривает также секторные подразделения, которые состав яют градиент от внутренних континентальных районов к побережьям. В статье представлен сравнительный анализ Северо-Восточной Азии с Аругими регионами Северного полушария по таким характеристикам как зональная структура, биоклиматы, типы раститецьности, основные таксоны деревьев и видовое богатство. Аля Северо-Восточной Азии, по сравнению с сопоставимыми районами восточной части Северной Америки и Европы, характерны более экстремальные и разнообразные климатические условия и высокое виАовое богатство. В какой-то степени это обусловлено изоляцией Японии, Камчатки, Сахалина и Кореи от Азиатского материка большими окраинными морями. Холодно-умеренные смешанные меса Северо-Восточной Азии и северо-востока Северной Америки сходны, хотя распространение первых на север ограничено южным краем вечной мерзмоты. Ряд типов растительности Северо-Восточной Азии уникален. А^я понимания организации растительного покрова необходимы сравнительные исследования, более полная информация о распространении таксонов и климате, разработка общего понятийного аппарата зональности. В статье акцентируется внимание на вопросах о различиях виАов, формирующих растительный покров разных регионов, и о факторах, ограничивающих их распространение. (Переведено редколлегией).

ключевые слова:

глобальное биоклиматическое зонирование, районирование, типичный умеренный кАимат, растительный район, Восточная Азия, ареал виАа, богатство виАов 


\section{INTRODUCTION}

Northeast Asia, in the context of this new journal Botanica Pacifica, involves that part of eastern Asia that borders or is directly influenced by the Pacific Ocean. This includes the Russian Far East (i.e. that part of Asiatic Russia that drains into the Pacific rather than the Arctic Ocean, from Chukotka to Primorye); the Kuril Islands, Sakhalin and the Japanese Archipelago; Manchuria and Korea; part of southern and eastern Mongolia; and much of northern and eastern China. The region is thus one with climates that permit forest vegetation throughout (except where too cold), primarily boreal, temperate-deciduous and mixed forests, both sub-boreal and those including admixtures of evergreen broad-leaved taxa from further south. Although the mainland areas border the Pacific, they are buffered from direct oceanic influence by the marginal seas (Sea of Okhotsk, Sea of Japan, East China Sea), a unique feature of East Asia. As a result, there are strong continentality gradients throughout the region.

Higher-latitude areas on other continents contain some similar vegetation types and zones, especially in the Northern Hemisphere (the Southern being too oceanic for continental climates). Northeast Asia is thus directly comparable to parts of northeastern North America (eastern Canada, northeastern USA) and, less directly, to parts of northern Europe. In terms of global zonation, the region includes the more humid boreal, cool-temperate and typical-temperate zones, plus parts of the polar zone and the respective mountain belts. Zonation in Russia also recognizes sectoral subdivisions that represent the gradient from the ultra-continental interior to the maritime Pacific areas. The purpose of this paper is to compare the zonation and some aspects of the vegetation of Northeast Asia with potentially similar regions on the other Northern Hemisphere continents. In doing this we look for what may be similar in the different regions and for characteristics that may be unique in Northeast Asia. Comparison includes zonation and vegetation types, main tree taxa, plant and vegetation limitation mechanisms, and species richness.

\section{B A C K G R O U N}

Vegetation study in East Asia, as elsewhere, developed within the individual countries in their own languages, which are much more distinct from each other and constitute much greater cultural barriers than in Europe. Chinese and Japanese, for example, share the use of Chinese characters but have nothing in common structurally.

Climatic descriptions and syntheses for Northeast Asia include those by Suslov (1961), Arakawa (1969) and Lydolph (1977). Bioclimatic zonation began with the East Asian regional zonation system by Kira (1945) but also includes interpretations by Kira $(1977,1991)$, Wolfe (1979) and Box (1995b). More specific bioclimatic zonation involves:

\footnotetext{
global zonation systems, as by Walter (1970, 1979; cf Walter \& Box 1976) and by Troll (1961, cf Troll \& Paffen 1964);

- the Japanese zonation (cf Kira 1977, 1991);

- the Korean zonation (Yim \& Kira 1975-1976), which follows Kira;
}

- the Chinese national geographical zonation (China Natural Geography Editorial Commission 1984; see interpretations such as by Zhao 1986);

- the Russian zonation system and refinements (e.g. Alekhin 1951; see interpretation for Pacific Russia by Krestov 2003); and

- an initial attempt to resolve the national zonation systems (Box 1995b, cf Box \& Choi 2003).

Perhaps the first attempt to synthesize East Asian vegetation patterns was the floristic treatment by Nakai (1938). General descriptions of national or regional vegetation (i.e. covering large areas) came along later and include:

- Kira (1949), Numata et al. (1972), Numata (1974), and
Miyawaki et al. (1980-89) for the vegetation of Japan;

Suzuki $(1952,1953)$, as one of the very few syntheses over multiple East Asian countries;

- Walter (1974) for the vegetation of higher-latitude Eurasia (mainly Russia);

- Yim \& Kira (1975-76) and Yim $(1977,1995)$ for Korea;

- Wang (1961) and Wu (1980, 1995) for the vegetation of present-day China, with summaries by Hou (1983), Song (1983), and map by Hou et al. (1979);

- Xu (1986), Zhou (1986, 1991), Chou \& Liu (1991), and Zhou \& $\mathrm{Zu}$ (1997) for the flora and vegetation of [Chinese] Manchuria; and

- Grishin (1995), Krestov (2003) and Nakamura et al. (2007) for vegetation of the Russian Far East, plus the classification by Ermakov et al. (2000) and the analyses of forest types by Krestov et al. (2006, 2007, 2010).

The vegetation of Northeast Asia as a region was finally described in English, in good detail, in Forest Vegetation of Northeast Asia (Kolbek et al. 2003a). This book includes chapters on the main vegetation regions by Krestov (2003) for eastern Russia, by Qian et al. (2003) for Chinese Manchuria, by Okitsu (2003) for northern Japan, and by Kolbek et al. (2003b) for northern Korea.

\section{DATA AND METHODS}

Data for this comparative analysis include the regional vegetation descriptions (see above), descriptions of East Asian species and their morphological characteristics, species range maps, climatic descriptions and data, and our own field vegetation data.

Especially good descriptions of plant species, with large color photographs, are available for Japan (e.g. Hayashi 1985), and some maps for Japan (Horikawa 1972, 1976) include some adjacent mainland areas; older maps do not (Hara 1959). Other range maps are only for the territory of the individual countries involved. For China the main source was "Higher Plants of China" (Fu \& Chen 1999; cf Institute of Botany 1972-1985). Maps for the Russian Far East were supplied by Pavel Krestov, scanned from Kharkevich (19851996) and Krasnoborov (1988-1997). These regional and more local maps could be supplemented in some cases by the pan-Eurasian range maps of Hultén and Fries (1986).

Climatic data, for comparisons and inferences, came from the world data-base compiled over the years by the first author. This data-base was supplemented for East Asia by data provided by Krestov, from the Russian national archives (Anonymous 1966-1971). In addition, climates were reconstructed for some field study sites, by geographically 
constrained three-dimensional inter/extrapolation software (programs TXTRAP and POLATE) developed by the first author. Envelope modeling involved a PC-adapted version of ECOSIEVE (see Box 1981), expanded for more rigorous calibration procedures. Analysis of relevé data involved, in particular, the summarizing routine RELSPECS for making overview tables (cf Box \& Fujiwara 2010, 2011).

Field data involved Braun-Blanquet relevés, which had been collected, following Fujiwara (1987), by the authors (and many helpers!) from: northern Zhejiang (1985); Chejudo and Mt. Seorak in South Korea (1989); Chinese Manchuria (1998-2006); southern (i.e. Chinese "Inner") Mongolia (20022010); mountainous and various other areas of China (20012006); Primorye (2003, 2006); Yakutia and Sakhalin (2006); and the lower Kolyma valley of northeastern Siberia (2007). For Japan many relevés were available from the "Vegetation of Japan" project (Miyawaki et al. 1980-1989).

\section{ZONATION}

Bioclimatic zonation began with the basic division of the world into torrid (tropical), temperate and frigid (polar) regions by Aristotle. In higher latitudes on continental east sides in the Northern Hemisphere, further subdivision recognizes a polar zone with very cool, short summers (not frost-free); a boreal zone with long severe winters but warmer summers (albeit short); and a temperate zone with warm summers but still significant frost in winter (e.g. Walter 1970, 1979, Hämet-Ahti et al. 1974, Box 1995b, 2003, Box \& Fujiwara 2004). In mountains of higher latitudes, the alpine belt (above treeline) generally corresponds to the polar zone and the subalpine belt to the boreal zone. Further south, the montane belt may correspond to the cool-temperate zone. In the boreal zone, though, any montane belt is already alpine.

In temperate latitudes, a warm-temperate subdivision is usually recognized, but opinions have differed about the remainder: should there be a total of two or three subdivisions? Japan and China have generally recognized only warmtemperate and cool-temperate, but their concepts of both are very different. Walter's global zonation also recognized only two, but his temperate prototype was in fact the higher-latitude nemoral climate of west-side Europe, i.e. cool-temperate. On continental east sides, mid-latitude climates tend to be more continental and the temperate zone broader. In eastern North America, for example, some tree species have distinctly "northern" and "southern" distributions, in genera such as Quercus, Acer, Fraxinus and Tilia. On the other hand, eastern North America also has major tree species that span the entire north-south temperate range, such as Fagus grandifolia, Quercus alba and Q. rubra, several Carya species, Acer rubrum, and major understorey trees such as Carpinus caroliniana, Ostrya virginica, and Cornus florida. The same is true of Fagus, several Quercus species, and some other deciduous tree genera in Japan.

This argues strongly for a symmetric division of the temperate zone into three sub-zones:

- a cool-temperate zone with cooler summers (due to higher latitude or oceanic influence), usually with significant admixtures of conifers such as Pinus koraiensis or P. strobus;

- a generally subcontinental 'typical temperate' zone, with four seasons of roughly equal expression and more completely deciduous forests (without conifers at maturity); and
- a warm-temperate zone with milder winters, quite warm-sultry summers, and generally evergreen broad-leaved forests as the zonal vegetation (deciduous in some places).

Logic suggests that the typical temperate should represent the widest portion, with cool and warm-temperate as smaller sub-zones possessing some transitional character. This three-part subdivision is used here, because it conforms better to all parts of the Northern Hemisphere.

The main concepts for these zones, critical temperature levels, and their significance for vegetation are summarized in Table 1. By this scheme, most of Hokkaido is cool-temperate and the northern half of Honshu is typical temperate (i.e. the range of lowland or foothill Fagus forests); Manchuria and subhumid eastern Inner Mongolia are cool-temperate and much of North China is typical temperate; Korea is mainly cool-temperate in the north and typical temperate in the south; and the Russian Far East is cool-temperate (or boreal to polar, further north). Eastern North America fits this three-division scheme well (e.g. Greller 1989); it would not fit into a two-part scheme because cool-temperate (cool summers) would apply only to New England and adjacent, but mild winters (warm-temperate) do not appear southward until one reaches the inner southeastern coastal plain. Europe is mostly cool-temperate north of the Alps and Pyrenees, due to the higher latitude and oceanic influence, but typical temperate to warm-temperate in the submediterranean south. In mountains of the temperate zone, the typical-temperate montane belt generally corresponds to cool-temperate (with mixed forests) and the warm-temperate montane belt to typical temperate (with more completely deciduous forests).

To this general zonation, the traditional Russian system adds the concept of "sectors" to represent the strong gradient from ultra-continental in central and eastern Siberia to the Pacific areas. Usually recognized are: an ultra-continental sector involving the extensive area of open larch woodland in eastern and part of central Siberia; a continental sector involving still inland areas such as Dahuria (upper Amur valley) and the easternmost larch region further north; a sub-maritime sector involving more nearly coastal areas such as Manchuria; a maritime sector involving less exposed coastal areas along the marginal seas, such as the coast of the Sea of Okhotsk; and an oceanic sector involving offshore islands (e.g. the Kurils) and some immediate oceanic coastal areas. It is not easy to represent these east-west sectors in a latitudinal zonation scheme, such as Table 1, but the sectors do represent a very useful modification of the basic zones. Note that the name 'Siberia' comes from the Sibir Khanate (descendants of Genghis Khan), which was just east of the Ural Mountains and was conquered by Ermak in 1582 to begin the Russian eastward expansion. Siberia thus refers more properly only to interior northern Asia and extends eastward only to the divide between the regions of Arctic and Pacific drainage. The Pacific region is called the [Russian] Far East, or Dal'nii Vostok. This Eurocentric term 'Far East' is condescending if applied to China or Japan, but within Russia it is quite acceptable, and several towns, such as Dal'nyegorsk in Primorye, have adopted dal'nye (far) as part of their names. 
Table 1. Basic Concepts of Global Bioclimatic Zonation

\begin{tabular}{|l|l|l|l|}
\hline Zones & Basic Concept & Temperature Limits & Significance and Vegetation Response \\
\hline Tropical & No frost or cold ever (lowlands) & $\begin{array}{l}\text { No temperatures ever } \\
<\text { about } 5-10^{\circ} \mathrm{C}\end{array}$ & $\begin{array}{l}\text { Vegetation well developed and evergreen, } \\
\text { unless significant dry season }\end{array}$ \\
\hline Subtropical & Almost tropical & $\begin{array}{l}\text { Occasional light frost or near-frost } \\
\text { (to about }-2^{\circ} \mathrm{C} \text { ) }\end{array}$ & $\begin{array}{l}\text { (same as for tropical, but perhaps with fewer } \\
\text { epiphytes and lianas) }\end{array}$ \\
\hline Warm-Temperate & Mild winters with some frost & $\begin{array}{l}\text { Light-moderate frost most years, } \\
\text { to about }-15^{\circ} \mathrm{C} \text {; winter means }>00^{\circ} \mathrm{C}\end{array}$ & $\begin{array}{l}\text { Vegetation still well developed and evergreen } \\
\text { (more or mostly deciduous if colder or drier) }\end{array}$ \\
\hline Temperate & $\begin{array}{l}\text { Frost significant, summers not } \\
\text { too hot }\end{array}$ & $\begin{array}{l}\text { Frost every year, to }<-15^{\circ} \mathrm{C} ; \\
\text { winter means }>\text { or }<0^{\circ} \mathrm{C}\end{array}$ & $\begin{array}{l}\text { Vegetation mainly winter-deciduous } \\
\text { (conifers secondary or disclimax) }\end{array}$ \\
\hline Cool-Temperate & Temperate but with cool summer & $\begin{array}{l}\text { Temperate but with summer means } \\
<\text { about } 20^{\circ} \mathrm{C} \text { winters milder if } \\
\text { oceanic }\end{array}$ & $\begin{array}{l}\text { Vegetation mainly deciduous }+ \text { conifers, } \\
\text { with broadleaf evergreens if winter milder } \\
\text { (as in Southern Hemisphere) }\end{array}$ \\
\hline $\begin{array}{l}\text { Boreal }(\mathrm{N} \text { Hem } \\
\text { only) }\end{array}$ & $\begin{array}{l}\text { Short cool summer, long severe } \\
\text { winter }\end{array}$ & $\begin{array}{l}1-3 \text { warm months }\left(>10^{\circ} \mathrm{C}\right) ; \\
\text { winter means to }<-40^{\circ} \mathrm{C}\end{array}$ & $\begin{array}{l}\text { Growing season too short for most } \\
\text { temperate trees: forests mainly coniferous }\end{array}$ \\
\hline Subpolar & Almost polar & $\begin{array}{l}\text { At most } 1 \text { warm month }\left(>10^{\circ}\right) ; \\
\text { winters severe to oceanic }\end{array}$ & $\begin{array}{l}\text { Last trees, widely spaced or in groves } \\
\text { (conifers or broad-deciduous) }\end{array}$ \\
\hline Polar & $\begin{array}{l}\text { Frost even in summer, long } \\
\text { severe winters }\end{array}$ & $\begin{array}{l}\text { Summer means }<10^{\circ} \mathrm{C} ; \\
\text { winters severe to oceanic }\end{array}$ & $\begin{array}{l}\text { Too cold for significant wood production: } \\
\text { plants mostly dwarf shrubs or herbaceous }\end{array}$ \\
\hline
\end{tabular}

The basic subdivision of the world into tropical, temperate and polar regions is based largely on the occurrence, frequency and degree of frost, as suggested first by Aristotle. The above scheme represents a geographically balanced zonation with basic zones and smaller transition areas (subtropical and subpolar). The temperate zone is divided further to recognize warmer (mild winter) and cooler (cool summer) variants. A distinct boreal zone (sometimes 'cold-temperate') of cold, continental climates also occurs across the large high-latitude land areas of the Northern Hemisphere. Use of the term 'subpolar' for boreal (in many systems) is misleading, since subpolar in fact represents a distinct transition in which forests and woodlands give way to treeless polar landscapes, much like the subalpine krummholz belt in temperate-zone mountains. Application of the term 'subtropical' to mid-latitudes areas, where winter temperatures fall far below freezing, is similarly misleading.

Zonation concepts and terminology in Russia, Japan and Korea largely follow global concepts. The Chinese national zonation scheme, however, is quite different, in that it focuses on the growing season and not the climate of the whole year. The Chinese system was developed in the 1950s (see Physical Regionalization Committee 19581959), influenced by the more northern perspective of the Russian system of that time. The Chinese system includes zones called liáng wên (涼温, = cool-warm), translated as cool-temperate, and nuăn wên (暖温, = warm-warm), translated as warm-temperate. The problem is that 'cooltemperate' is used for the zone of boreal conifer forests and 'warm-temperate' for the zone of temperate deciduous forests, including places like Harbin (interior Manchuria), where January mean temperatures are around $-20^{\circ} \mathrm{C}$ and extremes drop to $-35^{\circ} \mathrm{C}$. This is not a mild winter (warmtemperate) and may not even seem very "temperate", although summers are quite warm. The northernmost Chinese zone with evergreen broad-leaved forests is already called 'subtropical'. These terms are inappropriate and out of step with global zonation systems (see interpretation in Box 2003).

\section{VEGETATION REGIONS AND ZONATION}

The book on Forest Vegetation of Northeast Asia (Kolbek et al. 2003a) provides good explanations of the Russian zonation and sectoral divisions (Krestov 2003) and of the vegetation regions of the individual countries in Northeast Asia. These vegetation regions and their dominant taxa are summarized in Table 2. The main forest types are coniferous light (deciduous, i.e. Larix) and dark (evergreen, i.e. Picea and Abies) taiga in the boreal zone and subalpine belts; oakwoods (mainly Quercus mongolica) and mixed forests with Pinus koraiensis (sometimes Abies) in the cool-temperate zone and some montane belts; and deciduous mixed-oak forests in the temperate zone.

Zonation schemes for Northeast Asia have also been developed by various authors from outside the region, mainly for comparison with Europe. Among the best known of these are the scheme by Hämet-Ahti et al. (1974) focusing on Japan and adjacent regions; and the circumboreal scheme of Tuhkanen (1984). Europe, however, is on the windward west side of the large Eurasian land mass and is thus influenced much more by the adjacent ocean than is Northeast Asia. As a result, Europe has more moderated temperature regimes and its boreal, cool-temperate and typical-temperate zones occur at higher latitudes. Northeast Asia, on the other hand, has subcontinental climates right up to the Pacific coast (though called 'submaritime' and 'maritime' in the Russian sectoral terminology). A much more natural comparison for Northeast Asia is the east side of the other large Northern Hemisphere land mass, namely northeastern North America. This is also a region of quite continental to subcontinental east-side climates. Northeastern North America differs from Northeast Asia, however, in one important aspect: Hudson Bay and the lack of marginal seas such as the Sea of Japan. Northeastern North America was also glaciated much more than East Asia during at least the last of the Pleistocene glacial periods.

Even so, there are many parallels between the zonation and vegetation regions in Northeast Asia and northeastern North America. In Table 3, the main vegetation regions from Table 2 (plus somewhat further south) are placed, as vegetation types, into the global zonal framework, based on the available literature and field experience. For this, 
Table 2. Main Vegetation Regions in Northeastern Asia

\begin{tabular}{|c|c|c|c|}
\hline Zone & Vegetation Region & Locations & Vegetation Type/Dominants \\
\hline Polar & Arctic tundra & northernmost NE Asia & dwarf-shrub and lichen tundra \\
\hline \multirow[b]{2}{*}{ Subpolar } & Larch parkland & subcoastal NE Siberia & Larix cajanderi with Betula \\
\hline & Beringian woodlands & $\begin{array}{l}\text { maritime-oceanic } \\
\text { submaritime }\end{array}$ & $\begin{array}{l}\text { Alnus fruticosa woods } \\
\text { Pinus pumila woods }\end{array}$ \\
\hline \multirow{3}{*}{ Boreal } & Meadow birchwoods & S Kamchatka-mid Kurils & Betula ermanii woods \\
\hline & $\begin{array}{l}\text { Dark taiga (Picea) } \\
\text { - Picea-Abies } \\
\text { - Picea-Larix } \\
\text { - Abies-Larix }\end{array}$ & $\begin{array}{l}\text { E Okhotsk/Kamchatka } \\
\text { - southern W Okhotsk } \\
\text { - Okhotsk area } \\
\text { - Sakhalin }\end{array}$ & $\begin{array}{l}\text { Picea jezoensis } \\
\text { - with Abies nephrolepis } \\
\text { - with Larix cajanderi } \\
\text { - Abies spp. + Larix cajanderi }\end{array}$ \\
\hline & Larix woodland & E Siberia & Larix cajanderi $+L$. gmelinii (= L. daburica) \\
\hline \multirow{5}{*}{$\begin{array}{l}\text { Montane/ } \\
\text { Subalpine }\end{array}$} & $\begin{array}{l}\text { Picea forests, often with Abies, } \\
\text { Larix }\end{array}$ & $\begin{array}{l}\text { Hokkaido, Kurils, Sikhote-Alin, } \\
\text { W Okhotsk, central Kamchatka }\end{array}$ & $\begin{array}{l}\text { Picea jeroensis, with Abies sachalinensis, A. nephro- } \\
\text { lepis with Larix cajanderi }\end{array}$ \\
\hline & Abies forests & subalpine Japan & Abies mariesii, A. veitchii \\
\hline & $\begin{array}{l}\text { Larix montane forests } \\
\text { - Abies-Larix } \\
\text { - subalpine Larix }\end{array}$ & $\begin{array}{l}\text { N Korea, Da Xingan Ling } \\
\text { - N Korea } \\
\text { - central Honshu }\end{array}$ & $\begin{array}{l}\text { Larix olgensis, L. gmelinii } \\
\text { - Abies nephrolepis + Larix olgensis } \\
\text { - Larix kaempferi }\end{array}$ \\
\hline & Subalpine birchwoods & Japan (excl. S), S Kurils & Betula ermanii \\
\hline & Treeline pine thickets & NE Asia, Japan excl SW & Pinus pumila \\
\hline \multirow{5}{*}{$\begin{array}{l}\text { Cool- } \\
\text { Temperate }\end{array}$} & $\begin{array}{l}\text { Mesophytic forests, with pine in } \\
\text { hills/mtns }\end{array}$ & Manchuria-Korea-Primorye-S Kurils & $\begin{array}{l}\text { Fraxinus, Tilia, Acer, Ulmus, Q. mongolica, etc., with } \\
\text { Pinus koraiensis, some Abies }\end{array}$ \\
\hline & $\begin{array}{l}\text { Mongolian oak forests } \\
\text { - with Carpinus } \\
\text { - with pine (uplands) } \\
\text { - with Abies } \\
\end{array}$ & $\begin{array}{l}\text { N China - N Japan } \\
\text { - Korea-China (poor soils) } \\
\text { - Manchu-Korea-Primorye } \\
\text { - N Japan-S Sakhalin }\end{array}$ & $\begin{array}{l}\text { Q. mongolica, Q. liaotungensis } \\
\text { - with Carpinus spp. } \\
\text { - with Pinus koraiensis } \\
\text { - Q. crispula-Abies sachalinensis }\end{array}$ \\
\hline & Mixed Red Pine forest & N Korea foothills & Pinus densiflora-Fraxinus et al. \\
\hline & Coastal Abies-Picea forests & E Hokkaido & Abies sachalinensis, Picea jezoensis \\
\hline & Forest-steppe & Dauria-Hanka & Quercus mongolica-Betula davurica \\
\hline \multirow{3}{*}{$\begin{array}{l}\text { Temperate } \\
\text { (incl. some } \\
\text { warm- } \\
\text { temperate) }\end{array}$} & Beech forests & $\begin{array}{l}\text { Japan + Ulleung-do } \\
\text { Chinese S-central mtns }\end{array}$ & $\begin{array}{l}\text { Fagus crenata, F. japonica, F. multinervis } \\
\text { F. lucida, F. hayatae, F. engleriana, F. longipetiolata }\end{array}$ \\
\hline & Mixed-oak forests & $\begin{array}{l}\text { N China, Korea } \\
\text { Japan } \\
\text { S Japan-Korea }\end{array}$ & $\begin{array}{l}\text { Quercus acutissima, Q. aliena } \\
\text { Q. variabilis, Q.dentata, etc. } \\
\text { Quercus serrata, etc. }\end{array}$ \\
\hline & $\begin{array}{l}\text { Mongolian oak forests } \\
\text { - with Carpinus }\end{array}$ & $\begin{array}{l}\text { N China } \\
\text { - Korea-China }\end{array}$ & $\begin{array}{l}\text { Q. mongolica, Q. liaotungensis } \\
\text {-Q. mongolica-Carpinus spp. }\end{array}$ \\
\hline
\end{tabular}

This regionalization largely follows the chapters on Russia, North Korea, northern Japan, and northern China in Kolbek et al. (2003a). More detail on cooltemperate and temperate forest types was added especially from chapters in Box et al. (1995) and in Fujiwara (2008). A subpolar transition zone is added for the continental areas of northeastern Siberia, with open Larix parklands plus groves of Betula in a meadow-like matrix, as in the lower Kolyma valley.

Nomenclature: Picea jezoensis now includes P. ajanensis; Larix gmelini includes L. dahurica in some treatments, sometimes also L. cajanderi and L. olgensis; Quercus mongolica var. grosseserrata ( $\mathrm{N}$ Japan) is now Q. crispula; Q. liaotungensis and Q. wutaishanica are considered to be synonyms; and Quercus mongolica (s.l.) now includes Q. liaotungensis and Q. wutaishanica according to some conceptions (e.g. Wu \& Raven 1999).

several decisions had to be made. Fagus forests, for example, are considered 'typical temperate', since they occur from southern Hokkaido to upland Kyushu (and montane equivalent in the mountains of the evergreen region of southern China). Quercus mongolica forests are seen to involve two subtypes, cool-temperate mixed forests with Pinus koraiensis and typical temperate forests, mainly in northern China, largely without conifers. The extensive mixed-oak forests of northern China as well as Korea and Japan are considered 'typical temperate', although major species, such as Q. acutissima, Q. aliena, Q. serrata and Q. variabilis, extend further south and may form extensive post-disturbance secondary deciduous forests (e.g. Q. serrata in Japan) in the warm-temperate region of zonal evergreen broad-leaved forests. Quercus liaotungensis forests are considered cooltemperate (actually, cool-subhumid), since they extend into areas that are drier and sometimes cooler than the areas of Q. mongolica, $Q$. dentata, etc. The climatic affinities estimated for these and other species are shown in Table 4.
These main vegetation types of Northeast Asia are also compared (Table 3) with the main vegetation types and regions of eastern North America. This juxtaposition shows the zonal position and (Walter) climate of each vegetation type and identifies vegetation types that appear to have no counterpart. These types and regions that appear to be unique to Northeast Asia include:

\footnotetext{
the Beringian Woodlands of Pinus pumila or Almus fruticosa found in more maritime parts of subpolar Northeast Asia;

- the Meadow Birchwoods (Betula ermanii) and tall-forb meadows, of maritime boreal areas, especially those with heavy snowfall;

- the Larix forests and open woodlands of the more interior, ultra-continental parts of the [Russian] Far East and eastern Siberia;

the generally short, somewhat open Quercus mongolica oakwoods of more continental cool-temperate areas, as in Manchuria; and

- the "elm grasslands" (mainly Ulmus macrocarpa) of more subhumid northern China.
} 
Table 3. Main Vegetation Types of Northeast Asia and Corresponding Areas of Eastern North America

\begin{tabular}{|c|c|c|c|c|}
\hline \multicolumn{2}{|c|}{ Bioclimatic Zone } & \multirow{3}{*}{ Climate } & \multirow{2}{*}{$\begin{array}{l}\text { Northeastern Asia } \\
\text { Mainly heath tundra but also sedge tundra and lichen tundra }\end{array}$} & \multirow{2}{*}{\begin{tabular}{|l|} 
Eastern N America \\
Lichen tundra (high Arctic); \\
heath and sedge tundra (low Arctic) \\
\end{tabular}} \\
\hline \multirow{2}{*}{$\frac{\text { ैㅕㄴ }}{0}$} & Typical & & & \\
\hline & Alpine analog & & Upland, mainly heath tundra & Alpine tundra (e.g. Laurentian uplands) \\
\hline \multirow{2}{*}{$\begin{array}{l}\text { 离 } \\
0 \\
\frac{0}{3} \\
\text { के }\end{array}$} & Typical & \multirow[b]{2}{*}{ VIII-IX } & Open Larix gmelinii woodland, with Betula, Alnus & Open Picea mariana-lichen woodland \\
\hline & $\begin{array}{l}\text { Maritime } \\
\text { subpolar }\end{array}$ & & Beringian woodland (Pinus pumila, Alnus fruticosa) & --- \\
\hline \multirow{9}{*}{ 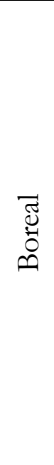 } & \multirow{2}{*}{$\begin{array}{c}\text { Maritime } \\
\text { boreal }\end{array}$} & \multirow{2}{*}{ VIIIm } & Meadow birchwood (B. ermanii + tall forbs) & --- \\
\hline & & & Picea and Abies forests, incl. pure stands & Picea rubens/glauca forests with Abies \\
\hline & $\begin{array}{l}\text { Typical } \\
\text { boreal }\end{array}$ & VIII & $\begin{array}{l}\text { Picea jezoensis, also with Abies nephrolepis, A. sachalinensis (S) } \\
\text { or Larix (esp Kamchatka); Betula platyphylla woods (e.g. } \\
\text { Changbai-shan, Siberia) }\end{array}$ & $\begin{array}{l}\text { Picea glauca forest, with Abies; P. mariana, } \\
\text { Pinus banksiana, Larix }\end{array}$ \\
\hline & $\begin{array}{c}\text { Ultra- } \\
\text { continental }\end{array}$ & VIIIc & Open Larix gmelinii woodland, with Pinus pumila & --- \\
\hline & \multirow{5}{*}{$\begin{array}{l}\text { Subalpine } \\
\text { analogs }\end{array}$} & & Picea-Abies forests (dark taiga) & Picea rubens-Abies fraseri forests \\
\hline & & & Abies pure stands: A. mariesii, A. veitchii (Japan) & Abies fraseri stands (e.g. Adirondacks) \\
\hline & & & Larix olgensis light taiga, with Picea, Rhododendron & --- \\
\hline & & & Betula ermanii woods, often with tall forbs & --- \\
\hline & & & Pinus pumila treeline thickets & --- \\
\hline \multirow{7}{*}{ 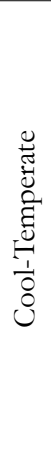 } & $\begin{array}{c}\text { Subboreal/ } \\
\text { montane } \\
\text { analog }\end{array}$ & VI-VIII & $\begin{array}{l}\text { Mixed mesophytic forests of Pinus koraiensis plus Tilia, } \\
\text { Fraxinus, Betula costata, Q. mongolica, etc. }\end{array}$ & $\begin{array}{l}\text { Northern mixed forests of Pinus strobus } \\
\text { plus Acer, Betula, Fagus, Q. rubra, etc. }\end{array}$ \\
\hline & \multirow{2}{*}{ Typical } & \multirow{2}{*}{ VI-VIm } & $\begin{array}{l}\text { Mesophytic deciduous forests with Tilia, Fraxinus, } \\
\text { Phellodendron, Kalopanax, Betula, Quercus, etc. }\end{array}$ & $\begin{array}{l}\text { Mesophytic deciduous forests (with } \\
\text { Fraxinus) }\end{array}$ \\
\hline & & & Quercus mongolica forests, often with Pinus koraiensis & $\begin{array}{l}\begin{array}{l}\text { Fagus-Acer, Acer-Tilia, Quercus rubra forests } \\
\text { (drier) }\end{array} \\
\end{array}$ \\
\hline & \multirow{2}{*}{ Maritime } & \multirow{2}{*}{ VIm } & Abies-Quercus forests (Hokkaido, Manchuria) & --- \\
\hline & & & Abies-Picea coastal forests (Hokkaido) & Abies-Picea coastal strip (Nova Scotia) \\
\hline & \multirow[t]{2}{*}{ Subhumid } & \multirow[t]{2}{*}{ VI-VII } & $\begin{array}{l}\text { Quercus mongolica and Q. liaotungensis woods, with Betula } \\
\text { davurica }\end{array}$ & Quercus macrocarpa woods \\
\hline & & & Populus tremula forest-steppe & Populus tremuloides grove belt \\
\hline \multirow{4}{*}{ 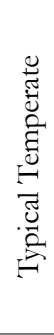 } & Typical & \multirow[t]{2}{*}{ VI } & $\begin{array}{l}\text { Fagus forests (Japan and Ulleung-do) } \\
\text { Mixed Quercus forests of N China, Korea, Japan with Q. } \\
\text { acutissima, Q. aliena, Q. variabilis, etc. } \\
\text { Quercus mongolica (s.l.) forests of N China }\end{array}$ & $\begin{array}{l}\text { Mesophytic forests (Fraxinus, etc.) } \\
\text { Quercus alba-Q. rubra forests, with Carya; } \\
\text { drier: with Q. prinus }\end{array}$ \\
\hline & $\begin{array}{l}\text { Montane ana- } \\
\text { logs in warm- } \\
\text { temp zone) }\end{array}$ & & Fagus forests on slopes (central China, S Japan) & $\begin{array}{l}\text { Appalachian "beech gaps" (Fagus) } \\
\text { Liriodendron "cove forests" Quercus-Castanea } \\
\text { forests (drier) }\end{array}$ \\
\hline & \multirow{2}{*}{ Subhumid } & \multirow{2}{*}{ VI-VII } & Low Quercus liaotungensis woods/savannas & Low Qu. macrocarpa woods/savannas \\
\hline & & & «Elm grasslands» (N China) & --- \\
\hline \multirow{2}{*}{ 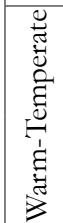 } & $\begin{array}{l}\text { Transitional } \\
\text { (mainly } \\
\text { deciduous) }\end{array}$ & VI-Ve & $\begin{array}{l}\text { Warm-temp deciduous forest (sensu Kira), esp. mixed } \\
\text { Quercus forests with Q. serrata, etc. }\end{array}$ & $\begin{array}{l}\text { Southern Quercus-Carya forests, with } \\
\text { Q. falcata, Q. nigra and } 2^{\circ} \text { pine }\end{array}$ \\
\hline & Zonal & Ve & Laurophyll forests of Machilus, Castanopsis and Cyclobalanopsis & $\begin{array}{l}\text { Quercus virginiana forests, + Magnolia } \\
\text { "Southern Mixed Hardwoods" } \\
\text { [laurophyll forests only topogenic] }\end{array}$ \\
\hline
\end{tabular}

Terminology for Northeast Asia mainly follows Krestov (Russia), Qian et al. (Chinese Manchuria), Okitsu (northern Japan) and Kolbek et al. (North Korea), as presented in "Forest Vegetation of Northeast Asia" (Kolbek et al. 2003). In addition: the term 'mesophytic' (sometimes 'mixed mesophytic') refers to forests with multiple deciduous canopy genera (none dominant); the term 'mixed' (otherwise) refers to forests with canopies of conifers plus deciduous broad-leaved trees. Concepts of zonation follow Kira and global zonation schemes (not the Chinese official zonation).

Oak forests of northern China are described by Chen et al. (1986), Chen (1995a), You et al. (2001), Wang et al. (2006), Tang et al. (2008), You \& Fujiwara (2008), and Zhi-Rong et al. (2010), among others; for Korea a classification was given by Kim (1990) and a summary of deciduous forests in general by Yim (1995). Chinese Fagus forests have been described by Zhu \& Yang (1985), Chen W.-L. (1995), Zhang (2000), Wang \& Fujiwara (2003), Wang et al. (2005), and Fujiwara et al. (2008), among others. Fagus forests have been summarized more generally by Peters (1997) and classified for Japan by Hukusima et al. (1995). Range limits and climatic affinities of Asian Fagus forests have been studied by Wolfe (1979), Cao \& Peters (1997), Shimano (1999) and Yagihashi et al. (2007). Picea forests have been summarized by Chen (1995b) for northern China and by Krestov \& Nakamura (2002) for eastern Russia.

Vegetation regions and terminology for eastern North America largely follow Braun (1950). Major vegetation summaries for eastern North America include Miyawaki et al. (1994) and chapters in books such as by Barbour \& Billings (1988). The term 'southern mixed hardwoods' refers to largely deciduous southern forests with admixtures of evergreen elements, both broad-leaved (e.g. Magnolia) and Pinus (Quarterman \& Keever 1962).

Climate types represent the expanded system of Walter (see Box 2002 or Box \& Fujiwara 2004): IX = polar, VIII = boreal, VII = temperate continental, $\mathrm{VI}=$ typical temperate, $\mathrm{Ve}=$ warm-temperate (subtypes: $\mathrm{m}=$ maritime, $\mathrm{c}=$ continental).

--- means no equivalent. 
North America does have Larix (only L. laricina, with a large range), some open northern oakwoods (as in Wisconsin), and small-leaved elms (e.g. Ulmus crassifolia), but these do not form extensive vegetation types similar to those of East Asia. Eastern North America also does not have any krummholz pine like Pinus pumila (or European P. mugo), and it does not have extensive, snowmelt-dependent tall-forb meadows similar to those of Northeast Asia (or Europe).

\section{PLANT TYPES OF TEMPERATE AND COOLER REGIONS}

Comparing plant ecological types may prove disappointing, since most genera (and some species) have circumpolar distributions. Even so, it may be instructive to look at the variation in morphological and ecological adaptations within the high-latitude Northern floras.

The different shapes of broad leaves are fairly well recognized, but the variation in "needles" and other linear leaves is interesting. Conifers, for example, may have flat or round needles, and some are compound, though mainly at more temperate or warm-temperate latitudes (e.g. Metasequoia, Taxodium, Sequoia) and in the Southern Hemisphere (e.g. Prumnopitys in New Zealand). The shape of needle leaves carries various implications for leaf function, as explained recently by Lusk (2008) with reference to pine needles. Among other differences, flat needles, as found in Abies and Tsuga, may:

- have lateral sclerids for better water transport away from the main leaf vein (cf Podocarpaceae);

- be more shade tolerant (because they capture light better, not necessarily because of higher efficiency per unit area or higher chlorophyll density); and thus

- have higher photosynthetic rates.

Tsuga is mainly a temperate or sub-boreal genus, while Abies also has many temperate-zone as well as subboreal species. Conifers with round needles include especially Picea, Larix and Pinus, only the latter of which has numerous temperate-zone (and even subtropical) species. In boreal areas, Picea species generally show levels of shade tolerance intermediate between Abies, on the one hand, and Pinus and broad-leaved taxa (e.g. Betula) on the other. Larix is usually light-demanding, and although shade-tolerant pines do exist (e.g. P. glabra, with somewhat darker green needles), most pines are also distinctly light-demanding.

Another way to suggest variation and diversity in plant ecological types (without actually identifying and describing the types) may be to look at numbers of species, within genera, in Northeast Asia versus comparable regions. Table 4 lists main tree and some other woody species of Northeast Asia, their zonal affinities and geographic ranges, and similar congeneric species (if they exist) in eastern North America. This listing does perhaps three things. It suggests ecological types and similar species within genera, providing a general overview of the important trees in the two regions. It shows the much greater richness (more species per genus) in East Asia than in eastern North America, also in the more northern latitudes (cf Qian et al. 2007). Finally, all of this suggests that the East Asian species may generally have more restricted ecological amplitudes, as has sometimes been suggested for eastern North American tree species relative to the (fewer) corresponding European tree species. Between East Asia and the other two regions, the discrepancy is perhaps most striking among the conifers.

Among conifers the diversity is clearly greater in Asia, in the higher latitudes as well as in mid-latitudes where China has so many conifer species. There is more balance among the more northern broad-leaved tree genera, i.e. those like Betula, Populus and Alnus that may occur far to the north in boreal forests. (Salix is not shown, since it includes so very many species in both regions.) Temperate East Asia has more major broad-leaved canopy tree genera than does eastern North America, including unique genera such as Phellodendron, Cyclocarya, Pterocarya and Aphananthe. Many genera, such as deciduous Fagus and Magnolia, also contain more species in East Asia than in North America, but this pattern does not extend uniformly to higher latitudes. North America also shows great diversity in some common genera, especially Quercus (s.s.), which includes the "red oak" group Erythrobalanus that does not occur at all (naturally) in Europe or East Asia. The USA has over 40 Quercus species, and Mexico is reputed to have over a hundred (Miller \& Lamb 1985). Eastern North America also has rather similar, multiple canopy tree species in important cool-temperate genera such as Fraxinus, Tilia and Ulmus. On the other hand, North America (excluding Mexican mountains) has only one species of Fagus (F. grandifolia), but it occurs in pure stands almost only on humid mountain slopes, much like the Fagus species in central China.

Because East Asia often has more species per genus, there is often no or only one real "vicariant" equivalent in eastern North America. Among oaks, for example, although eastern North America has a large number of deciduous oak species, there are no real individual equivalents for most deciduous oak species of temperate East Asia, including Quercus acutissima, Q. aliena, Q. mongolica, Q. serrata, and Q. variabilis. Even though one (Q. aliena) is called "Oriental white oak" in English, it has a much narrower north-south range than the 'white oak' of eastern North America $(Q$. alba). Eastern North America does indeed have deciduous mixed-oak forests, quite extensively, but the main oak species, except for $Q$. alba, are all from the 'red oak' group (Erythrobalanus, with Q. rubra, Q. velutina, Q. coccinea, etc.) that does not occur in East Asia.

\section{LIMITS AND RANGES OF TAXA}

In high latitudes, most of the limits on plant and vegetation development involve aspects of temperature. These main climatic limitations are summarized in Table 5. Since many of the plants are adapted to cold, the most important determinants of vegetation patterns often involve summer warmth. Previous global modeling (Box 1995c) had suggested that accurate representation of some northern high-latitude vegetation patterns requires representation of both temperature thresholds and total growing-season warmth, i.e. some plant types seem to respond to one or the other first. Different aspects of winter cold include low mean and minimum temperatures (which may not differ greatly at high latitude) and individual extremecold events. Some moisture in winter may be required, if not directly then as snow cover, which buffers shorter evergreen plants against 
Table 4. Main Tree Species of Northeast Asia and Congeneric Species in Northeastern North America

\begin{tabular}{|c|c|c|c|c|}
\hline Genus & Zone & Species in NE Asia & Range & $\begin{array}{l}\text { N America } \\
\text { (eastern) }\end{array}$ \\
\hline \multicolumn{5}{|l|}{ Conifers } \\
\hline \multirow{8}{*}{ Abies } & boreal & A. sibirica (sec. balsamea) & Siberia & A. balsamea \\
\hline & subalpine & A. veitchii (cf nephrolepis) & Honshu mtns & A. fraseri \\
\hline & subalpine & A. mariesii (sec. amabilis) & Honshu mtns (deep snow) & \\
\hline & submaritime-boreal & A. nephrolepis & Primorye-Amur, Korea-E Manchuria & \\
\hline & maritime cool-boreal & A. sachalinensis & Sakhalin, N Japan, Kamchatka & \\
\hline & montane & A. bomolepis & Japan Alps, Shikoku mtns & \\
\hline & c-temperate & A. bolophylla & S Primorye, N Korea, S Manchuria & \\
\hline & temperate/w-temp & A. firma & Japan: Pacific + S & \\
\hline \multirow{5}{*}{ Picea } & boreal & P. obovata (cf P. abies) & Siberia & P. glauca, P. mariana \\
\hline & subalpine & P. maximowiczii & Japan Alps only (Nagano-Yamanashi) & --- \\
\hline & maritime-boreal & P. glehnii & Hokkaido-S Sakhalin & P. rubens \\
\hline & maritime-boreal & P. koraiensis (cf obovata) & Manchuria-N Korea-Amur & \\
\hline & maritime-boreal & P. jezoensis (incl. ajanensis) & Manchuria-N Korea, Amur, Hokkaido, Kamchatka & \\
\hline \multirow{4}{*}{ Pinus (2 ndls) } & boreal-temperate & P. sylvestris & N Europe-Siberia (not coldest) -Manchuria & P. banksiana \\
\hline & temperate & P. densiflora & Japan excl Hokkaido, Korea-E Manchuria & P. resinosa \\
\hline & temperate/w-temp & P. thunbergii & coastal Japan excl Hokkaido, S Korea & --- \\
\hline & temperate/w-temp & P. tabulaeformis & central China-Manchuria & P. taeda, echinata, etc. \\
\hline Pinus (5 ndls) & boreal/subalpine & P. pumila & E Russia, N Kor, Manchuria, subalp Japan & \\
\hline - hard & boreal & P. sibirica & Urals to Dahuria & --- \\
\hline - erect & subalpine & P. parv. v. pentaphylla & central-N Honshu mtns, S Hokk, Hokk mtns & (western NAm only) \\
\hline & cool-temperate & P. parviflora & central-S Japan mtns + Ulleung-do & --- \\
\hline - soft & cool-temp/subboreal & P. koraiensis & Korea-E Manchuria, Primorye, mid-Honshu mtns. & P. strobus \\
\hline \multirow{2}{*}{ Tsuga } & subalpine & Ts. diversifolia & central-S Japan & --- \\
\hline & temperate/montane & Ts. sieboldii & central-S Japan, Ulleung-do & Ts. canadensis \\
\hline Cryptomeria & coastal/mtns & C. japonica & Japan excl Hokkaido & --- \\
\hline Taxus & temperate/c-temp & T. cuspidata & Manchuria-Korea-Primorye, Japan & (western NAm only) \\
\hline \multirow{2}{*}{ Chamaecyparis } & temperate/w-temp & Ch. obtusa & central-S Japan & Ch. thyoides \\
\hline & temperate/subalpine & Ch. pisifera & N Honshu-Kyushu & --- \\
\hline \multirow{2}{*}{ Thuja } & cool-temperate & Th. koraiensis & Korea-Changbaishan & Th. occidentalis \\
\hline & temperate/w-temp & Th. standishii & Honshu-Shikoku & --- \\
\hline \multirow{3}{*}{ Juniperus } & $\mathrm{cool} /$ boreal & J. communis & across northern/temperate Eurasia (and NAm) & [J. communis] \\
\hline & $\mathrm{cool} /$ temperate & J. rigida & N Chin-Korea-Japan-Primorye-Sakhalin & --- \\
\hline & temperate/w-temp & J. chinensis & Japan excl Hokk, Korea, China & J. virginiana \\
\hline \multicolumn{5}{|c|}{ Short-Summer Broad-Leaved Trees } \\
\hline \multirow{4}{*}{ Alnus } & subpolar/subalpine & A. fruticosa & northern Eurasia-Manchuria-Korea & A. serrulata, $A$. rugosa \\
\hline & c-temperate & $\begin{array}{l}\text { A. mandshurica [fruticosa } \\
\text { ssp] }\end{array}$ & Manchuria & \multirow{4}{*}{---} \\
\hline & c-temp/temperate & $\begin{array}{l}\text { A. hirsuta (incl. sibirica, } \\
\text { tinctoria) }\end{array}$ & Manchuria, N Japan, Sakhalin-Okhotsk-Kamchatka & \\
\hline & temperate/c-temp & A. japonica & Japan, China, NE Asia & \\
\hline \multirow{7}{*}{ Betula } & boreal & B. pendula & Siberia & \\
\hline & boreal/c-temperate & B. platyphylla (white) & $\begin{array}{l}\text { central Siberia-Far East, Kurils, Korea, central-N } \\
\text { Japan, China excl SE }\end{array}$ & B. papyrifera \\
\hline & $\begin{array}{l}\text { maritime-boreal/ } \\
\text { subalpine }\end{array}$ & $\begin{array}{l}\text { B. ermanii (yellowish- } \\
\text { gray) }\end{array}$ & $\begin{array}{l}\text { Manchuria-Dahuria-Chukotka-Kamchatka, Kurils, N } \\
\text { Japan, Korea }\end{array}$ & \multirow[t]{2}{*}{-} \\
\hline & c-subboreal & B. davurica (gray) & Dahuria-Manchuria-Primorye-Korea, N Japan & \\
\hline & c-temperate & $\begin{array}{l}\text { B. costata (yellowish- } \\
\text { white) }\end{array}$ & Hebei-Manchuria-Primorye, Korea & B. lutea \\
\hline & c-temperate & $\begin{array}{l}\text { B. maximowicziana } \\
\text { (pioneer) }\end{array}$ & Hokkaido, central-N Honshu & --- \\
\hline & c-temp/temperate & B. chinensis (gray) & N China-Manchuria-N Korea & B. lenta \\
\hline \multirow{6}{*}{ Populus } & [sub]-boreal & P. suaveolens (gray) & N Mongolia-E Russia-Manchuria & P. balsamifera \\
\hline & subboreal-boreal & P. tremula (white) & Atlantic Europe to Far East & P. tremuloides \\
\hline & subboreal & P. maximoniczii & E Mongol-Dahuria-Manchuria-N Korea, N Japan & \\
\hline & c-temperate & P. koreana & N China-Manchuria-N Korea-Primorye, N Japan & \\
\hline & c-temp/temperate & P. davidiana (gray) & Mongolia-China-Manchuria-E Russia, N Korea & --- \\
\hline & cool-temp/temperate & P. sieboldii & Japan & \\
\hline Sorblo & temperate/c-temp & S. alnifolia & Manchuria, Japan, Russia? & \\
\hline Jorbus & temperate-subboreal & S. commixta & cooler Japan, Korea, Sakhalin & S. americana \\
\hline Major Br & -Leaved Canopy Tree & & & \\
\hline & temperate & F. crenata & Japan incl S Hokkaido & F. grandifolia \\
\hline & temperate w/o snow & F. japonica & Japan excl J-Sea, Hokkaido & \\
\hline Fagus & & F. lucida (cf crenata) & mtns of central China & \\
\hline & montane & F. engleriana (cf japonica) & mtns of central China: N-most & \\
\hline & & F. longipetiolata & mtns of central China: S-most & \\
\hline
\end{tabular}


Table 4. Continued

\begin{tabular}{|c|c|c|c|c|}
\hline Genus & Zone & Species in NE Asia & Range & $\begin{array}{l}\text { N America } \\
\text { (eastern) }\end{array}$ \\
\hline \multicolumn{5}{|c|}{ Major Broad-Leaved Canopy Trees } \\
\hline Fagus & subtrop/w-temp mnt & F. hayatae & low mtns of E China, Taiwan & |-- \\
\hline \multirow{8}{*}{$\begin{array}{l}\text { Quercus } \\
\text { (Leucobalanus) }\end{array}$} & c-temperate & Q. mongolica & N Chin-E Mong-Kor-Manchu-Far East, Sakhalin & QQ. alba] \\
\hline & c-temperate & Q. mong. v. grosseserrata & Japan esp N (sporadic in Korea) & --- \\
\hline & cool/temp subhumid & $\begin{array}{l}\text { Q. liaotungensis/ } \\
\text { wutaishanica }\end{array}$ & Gansu-central China-Manchuria & Q. macrocarpa \\
\hline & temperate & Q. dentata & $\mathrm{N}$ to upland SW China, Korea-Primorye, Japan & \multirow{6}{*}{--} \\
\hline & temperate/w-temp & $\begin{array}{l}\text { Q. aliena } \\
\text { (Oriental white oak) }\end{array}$ & central China, Korea, Japan (mainly S) & \\
\hline & temperate/w-temp & $\begin{array}{l}\text { Q. serrata (main w-temp. } \\
\text { deciduous oak) }\end{array}$ & central China, Korea, Japan to S Hokkaido & \\
\hline & temperate/w-temp & $\begin{array}{l}\text { Q. variabilis } \\
\text { (Chinese oak) }\end{array}$ & N to S China, Korea, S Japan & \\
\hline & temperate/w-temp & Q. acutissima & $\mathrm{N}$ to $\mathrm{S}$ China+Hainan, Korea-Manchu, Jap excl N & \\
\hline \multirow{4}{*}{ Carpinus } & c-temperate & C. cordata & Manchuria-Primorye-Korea, mainly N Japan & \\
\hline & temperate/w-temp & C. laxiflora (cf fargesiana) & Japan-Korea-China & C. caroliniana \\
\hline & temperate/w-temp & C. tschonoskii & Japan excl N, Korea-Manchuria-N China & \multirow{2}{*}{--} \\
\hline & temperate/w-temp & C. japonica & Japan excl Hokkaido & \\
\hline Celtis & temperate & C. bungeana & N Korea-S Manchuria-E Mongolia & C. occidentalis $(\mathrm{N})$ \\
\hline \multirow{4}{*}{ Fraxinus } & c-temperate & F. mandshurica & Manchu-Dahuria-E Mong, N Kor, N Jap (wetter) & $\begin{array}{l}\text { F. pennsylvanica, } \\
\text { F. nigra }\end{array}$ \\
\hline & temperate/cool & F. rbynchopbylla & Manchu-Primor-N Kor-cent. \& E China & F. americana \\
\hline & temperate/cool & F. lanuginosa & Japan + Korea ("medium tree" - cf F. ornus?) & \multirow[t]{2}{*}{ 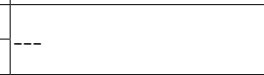 } \\
\hline & temperate/w-temp & F. sieboldiana & Japan, Korea, E China (occurs with Q. serrata) & \\
\hline \multirow{4}{*}{ Tilia } & c-temperate & $\begin{array}{l}\text { T. amurensis } \\
\text { (incl. divaricata) }\end{array}$ & Amur-Primorye, Manchuria, N Korea & T. americana \\
\hline & c-temperate & T. mandshurica & Hebei-Manchu-Prim-N Kor (not upper Amur) & \multirow{3}{*}{---} \\
\hline & c-temperate & T. maximowicziana & Hokkaido-Honshu (only) & \\
\hline & c-temperate & T. japonica (cf amurensis) & Japan + E China & \\
\hline \multirow{6}{*}{ Ulmus } & temperate/c-temp & U. davidiana & central-N China, Primorye & U. americana, U. rubra \\
\hline & temperate/c-temp & $\begin{array}{l}\text { U. japonica } \\
(=U . \text { propinqua })\end{array}$ & Dahuria-S Manchu-Kor-Prim, Japan esp N, S Sakh & \multirow{3}{*}{ 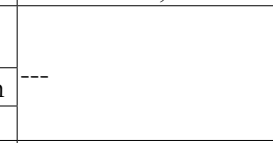 } \\
\hline & temperate & U. laciniata & Dahuria-Manchu-Korea-Prim, N China, Japan, Sakh & \\
\hline & temperate & U. macrocarpa & Dahuria-Manchuria-Primorye, N Korea & \\
\hline & temperate-subhumid & U. pumila & Uyghur-N China-Manchu, S to central \& E China & cf $U$. crassifolia \\
\hline & w-temperate & U. parvifolia & E-S-central China, S Japan & \multirow{2}{*}{ 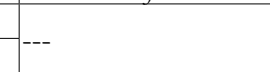 } \\
\hline Zelkova & temperate/w-temp & Z. serrata & Japan, Korea, Taiwan & \\
\hline
\end{tabular}

The table includes main forest tree species, arranged loosely from north to south (within genus). Main sources included range maps (mostly for the individual countries), field guides (especially Hayashi 1985), website maps, website descriptions (especially in the Flora of China, at www.eFloras.org), and field experience. Errors certainly remain, some due to conflicting taxonomies and species concepts in different countries and at different times. Eastern North America (NAm) generally has fewer species in these deciduous tree genera, although some may not be similar and are not listed.

East Asia also has many relict conifers, most of which occur further south than Northeast Asia and have no counterparts elsewhere. Among these are: - subtropical Glyptostrobus pensilis in SE China;

- warm-temperate to subtropical Cunninghamia lanceolata and Keteleeria davidiana in southern China, and Podocarpus nagi in southernmost Japan, Taiwan and Hainan;

- temperate to warm-temperate Sciadopitys verticillata and Thujopsis dolobrata in central to southern Japan, and Podocarpus macrophyllus in southern Japan, Taiwan, and eastern and southern China;

- temperate Metasequoia glyptostroboides in central China and Torreya nucifera in central to southern Japan and Korea;

- cool-temperate to warm-temperate Cephalotaxus harringtonia in central to southern Japan, Korea and Manchuria; and

- temperate-subhumid Platycladus orientalis (= Thuja orientalis) from Hebei to southern Gansu in northern China.

Abbreviations: c-temp, cool $=$ cool-temperate; $w$-temp, warm $=$ warm-temperate. --- means no equivalent.

extreme cold. Where snow is heavy, an extended snowmelt season in spring and early summer may ensure permanently moist conditions throughout the growing season. Some taxa such as Fagus, on the other hand, do not tolerate saturated soil for long periods and so may have upper limits for total moisture. Growing seasons involve simultaneous availability of warmth and moisture. Most temperate-zone broad-leaved trees require about four months of summer warmth (mean temperature $>$ $10^{\circ} \mathrm{C}$ ) in order to produce viable seeds and reserves for the next year (e.g. Walter 1979: p. 164, cf Archibold 1995: p. 166), as opposed to at least 30 similarly warm days for boreal conifers.
The most important limiting temperatures for plants are called cardinal temperatures and are summarized in Table 5. Broad-leaved evergreen woody taxa are generally excluded from higher-latitude areas by even short-term occurrences of temperatures below about $-15^{\circ} \mathrm{C}$ (cf Woodward 1987). Deciduous trees, however, may also have temperature limits, as shown by comparing range limits with the temperatures at which boles are damaged by freezing of the water within them. Internal freezing can be identified by monitoring exotherms, i.e. the emissions of latent heat that occur at freezing (George et al. 1974). A first exotherm 
Table 5. Main Climatic Limitations for Trees in Northern Higher Latitudes

\begin{tabular}{|c|c|}
\hline Factor & Aspect and Possible Variables for its Representation in Models \\
\hline Warmth & Threshold for mean summer temperature (Tmax) or Temperature sum for growing season (BT) \\
\hline Coldness & $\begin{array}{l}\text { Lower limits for: mean temperature of coldest month (Tmin); mean winter temperature minima (Tmmin); } \\
\text { absolute minimum temperature (Tabmin) }\end{array}$ \\
\hline Moisture (total) & Minimum annual precipitation requirement or Minimum moisture balance $(\mathrm{P} / \mathrm{PET})$ \\
\hline Moisture (seasonal) & Winter precipitation needs (Pmin) or Winter P/PET need (cf spring snowmelt and permanent GS moisture) \\
\hline Snow depth & Minimum need (for protection against cold) or maximum tolerance (cf length of snow-free period) \\
\hline Soil aeration & Requirement for aerobic conditions (Pmin, but may require more complete soil water budget) \\
\hline $\begin{array}{l}\text { Growing season: } \\
\text { - warm period } \\
\text { - warmth }+ \text { moisture }\end{array}$ & $\begin{array}{l}\text { Minimum length for fruit ripening and seed preparation } \\
\text { (if no significant climatic dry season, e.g. summer) } \\
\text { (if some season is significantly dry: summer or monsoonal spring) }\end{array}$ \\
\hline
\end{tabular}

Some northern range limits seem to involve both summer temperature thresholds and total growing season warmth. Range limits due to winter cold may involve mean temperatures near or below freezing, persisting below-freezing minima, or one-time extreme-cold events. In forested areas East Asia, summer precipitation usually is not limiting. In winter, however, moisture may be needed, especially snow for buffering short evergreen taxa against of extreme cold or for extending the spring snowmelt season to ensure permanently moist conditions throughout the growing season. On the other hand, some taxa such as Fagus do not tolerate saturated soil for long periods and may have upper limits for total or winter precipitation (or surrogate). At higher latitudes, temperatezone trees may be limited by growing seasons too short for production of viable seeds.

Abbreviations: $\mathrm{P}=$ precipitation, $\mathrm{PET}=$ potential evapotranspiration, $\mathrm{GS}=$ growing season (simultaneous warmth plus moisture), $\mathrm{BT}=$ biotemperature (sum of monthly means $>0^{\circ} \mathrm{C}$, divided by 12), Tmax $=$ mean temperature of warmest month, Tmin $=$ mean temperature of coldest month, Tmmin $=$ mean minimum winter temperature (coldest month), Tabmin $=$ absolute minimum temperature (lowest ever measured), Pmin $=$ average precipitation in the driest month (usually winter).

is usually observed at temperatures around $-15^{\circ} \mathrm{C}$, which may represent freezing of water in leaves and smaller twigs. A second exotherm, at about $-40^{\circ} \mathrm{C}$, represents the freezing of water in tree boles and coincides with the northern limits of most trees with ring-porous wood (most truly temperate Angiosperm tree taxa; see also Arris \& Eagleson 1989). Most boreal deciduous trees have diffuse-porous wood (e.g. Woodcock 1994; cf Taneda \& Sperry 2008) and can survive further north, since their boles do not freeze until temperatures below $-50^{\circ} \mathrm{C}$.

One apparently unique feature of Northeast Asia involves the high degree of continentality. In some areas the annual temperature range is so great that it is possible to have the four warm months needed for temperate trees and still have a mean annual temperature near or below $0^{\circ} \mathrm{C}$. As one goes north (or up in elevation), mean annual temperature may drop below the critical threshold for permafrost (about $-1^{\circ} \mathrm{C}$, maybe $-2^{\circ} \mathrm{C}$, depending on soil texture and water content) before the length of the warm period falls below four months. The normal zonation is thus truncated abruptly, and temperate deciduous forests may give way suddenly to larchwoods, with little or no transitional mixed forest (see Box et al. 2001). This does not occur in Europe or North America because the annual temperature range is not sufficiently extreme.

Some aspects of climatic limitation can be studied by means of climatic envelope models (cf Box 1981, 1995a), which relate the geographic ranges of taxa to limiting values of particular climatic variables that represent factors deemed critical. Construction of good climatic envelopes requires reliable range maps as well as adequate climatic data and physiological understanding. Sets of climatic envelopes were constructed by the first author, using variables suggested in Table 6 and others, for the main tree species of eastern North America ( $n=120$; Box et al. 1993, Box \& Manthey 2006) and of Europe ( $\mathrm{n}=58$; cf Box \& Manthey 2006, Manthey \& Box 2007). Calibration of climatic envelopes for the main tree species of temperate East Asia, however, was much more difficult because of:

- the much more discontinuous nature of the land mass (islands versus mainland); and

- lack of complete information on the full geographic ranges of the species, especially the lack of range maps.

There appeared to be a much greater degree of overlap of species ranges in East Asia, which manifested itself as multiple species occupying nearly identical climate spaces. This often involves mainland-island species pairs and suggests small differences that arose during the different historical development patterns of taxa on the mainland versus Japan or other offshore islands. A good example is the

Table 6. Cardinal Temperature Limits for Plant Types

\begin{tabular}{|r|l|}
\hline Limits & Limitations \\
\hline \multicolumn{2}{|c|}{ Upper limits: } \\
\hline $40-45^{\circ} \mathrm{C}$ & collapse of respiratory mechanism for most species \\
\hline Lower limits: \\
\hline $5^{\circ} \mathrm{C}$ & $\begin{array}{l}\text { many tropical species; also most unreinforced } \\
\text { malacophylls }\end{array}$ \\
\hline$-2^{\circ} \mathrm{C}$ & most subtropical species \\
\hline$-15^{\circ} \mathrm{C}$ & $\begin{array}{l}\text { temperate evergreen broad-leaved woody species } \\
\text { (foliage freezing) }\end{array}$ \\
\hline$-40^{\circ} \mathrm{C}$ & broad-leaved trees with ring-porous trunkwood \\
\hline$<-50^{\circ} \mathrm{C}$ & broad-leaved trees with diffuse-porous trunkwood \\
\hline
\end{tabular}

Upper cardinal temperatures involve limitations to plant metabolism, such as collapse of the respiratory mechanism at high temperatures. Lower cardinal temperatures are posed by potential damage to cells and tissues, as from freezing of intra-cellular fluids. Limitation often results from single events, such as extreme overnight low temperature, for which local absolute minimum temperature is often a useful index. Most limiting values were first suggested by Sakai (1971), Larcher $(1954,1973)$ and corroborated by Woodward (1987). Limitation of even winter-deciduous trees by extreme cold, based on trunkwood structure, was demonstrated by George et al. (1974; see also Archibold 1995; cf Arris \& Eagleson 1989). See also a recent review by Larcher (2005), as well as the book by Sakai \& Larcher (1987). 
mainland species Quercus mongolica and the Japanese species Q. mongolica var. grosseserrata, now called $Q$. crispula. Other obvious overlaps, suggesting questions to be studied, involve:

- the various deciduous oak species ranging over much of the temperate mainland and temperate Japan, e.g. Q. aliena, Q. acutissima, Q. dentata, Q. serrata, Q. variabilis;

- the Fagus species of Japan and of the mountains of south-central to southeastern China; and

- the various species of Fraxinus, Ulmus, Tilia, and other major deciduous tree genera.

This overlap may be partly inevitable, given the large numbers of species per genus in East Asia, but it appears to be exacerbated by the complex, discontinuous topography. In order to study this problem of niche overlap, the climatic envelopes of the main deciduous and coniferous tree species of Northeast Asia have also been re-calibrated very empirically, in order to reflect the geographic taxon ranges as closely as possible (rather than to reflect physiological potentials, as is usually more desirable). This work is still ongoing, however, and depends on new range maps or other data on taxon range limits and limiting factors.

Recognition as different species generally requires various kinds of evidence, including morphological as well as reproductive (e.g. different flowering and fruiting times). Even so, differences may sometimes be interpreted better as different varieties or subspecies (as was done earlier) than as different species. In this regard one must note the recent suggestions that $Q$. liaotungensis and $Q$. wutaishanica are the same species (Zhao \& Tian 2001) and that both are even included in the one species Q. mongolica (Wu \& Raven 1999).

\section{VEGETATION SIMILARITIES AND RICHNESS}

Similarity in the floras and vegetation of East Asia and eastern North America has been well known since the time of Asa Gray (1846, 1859, cf Graham 1972, Boufford \& Spongberg 1983). Perhaps more than anywhere else, the first author was struck by this similarity upon first seeing an East Asian cool-temperate mixed forest involving fiveneedle Pinus koraiensis, which seems so similar to P. strobus in the northeastern USA and southeastern Canada. A search of our relevé data-bases from both regions yielded only one relevé example of a relatively rich forest in each region. These relevés are juxtaposed in Table 7, with the genus at far left and the respective species and their amounts in columns to the right. Both samples are from about $43^{\circ} \mathrm{N}$ latitude and are of about the same size. The East Asian example is from near Vladivostok, and the North American example is from Bronte Creek, west of Toronto in southern Ontario (further inland but near Lake Ontario). The East Asian example has more species (87 versus 74 ), but the similarity in tree taxa as well as understorey synusiae (families and genera if not always obviously vicariant species) is striking.

We could not do the same comparison for boreal forests around the Northern Hemisphere. It may, however, be useful to ask whether this similarity in structure, at plot scale, extends also to boreal forests, and whether East Asia also has consistently higher species richness in boreal latitudes.

In a study using relevé data from boreal to warmtemperate areas of eastern North America, it was found that species richness, at least at plot scale, seems to be controlled fairly consistently by richness in the herb layer (Box \& Fujiwara 2011). Furthermore, it appeared in that study that herb-layer richness was strongly related, in turn, to topographic situations and other substrate aspects. In addition to higher species richness on gentle terrain with deep soil, richness was also:

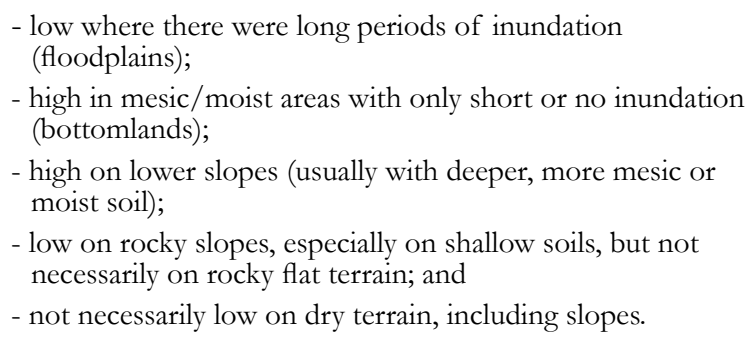

Do the same patterns obtain in East Asia, and do they extend to higher latitudes and to the greater diversity of climates found in East Asia?

\section{CONCLUSIONS}

Results from this initial regional comparison are necessarily superficial but do suggest some interesting features and areas for future study. First of all, several features can be recognized as perhaps unique in Northeast Asia, or at least better developed than on other continents:

1) the extensive areas of larch woodland in the most ultracontinental areas of boreal eastern Siberia (mean January temperatures $<$ about $-30^{\circ} \mathrm{C}$ );

2) the truncation of the temperate forest zone by the sudden northward appearance of permafrost, as the wide seasonal temperature amplitude permits mean annual temperature to fall below the permafrost threshold (about $-1^{\circ} \mathrm{C}$ ) before the growing season becomes too short or cool for temperate-zone trees;

3) the maritime influence on climates significantly inland, due to the marginal seas (which no other continent has so extensively);

4) the generally higher species richness in comparable vegetation types of East Asia, perhaps extending into boreal latitudes, relative to northeastern North America and Europe;

5) the many similar but "different" congeneric species that occur in very similar climatic spaces in East Asia, usually with one on the mainland and the other on offshore islands.

The maritime influence (item 3) and resulting east-west continentality gradient produce the sectors of the Russian classification system, including continental, submaritime, maritime, and oceanic. In comparison with other regions, though, the Russian 'submaritime' is already 'continental' (as in the example of cool-temperate mixed forests in Primorye and Ontario).

These and other observations also suggest some real needs concerning the vegetation of Northeast Asia, as well as East Asia in general. This new journal and the two international vegetation symposia in East Asia this year (2012, in Vladivostok and Mokpo) perhaps provide an opportunity to launch major efforts directed at these needs.

One important need is for more, and more extensive, species range maps, not just for individual countries but for the whole East Asian region where the species occur. In some cases this may even involve most of the entire eastwest span of higher-latitude Eurasia. 
Table 7. Comparison of Two Mixed-Forest Stands in Cool-Temperate East Asia and Eastern North America

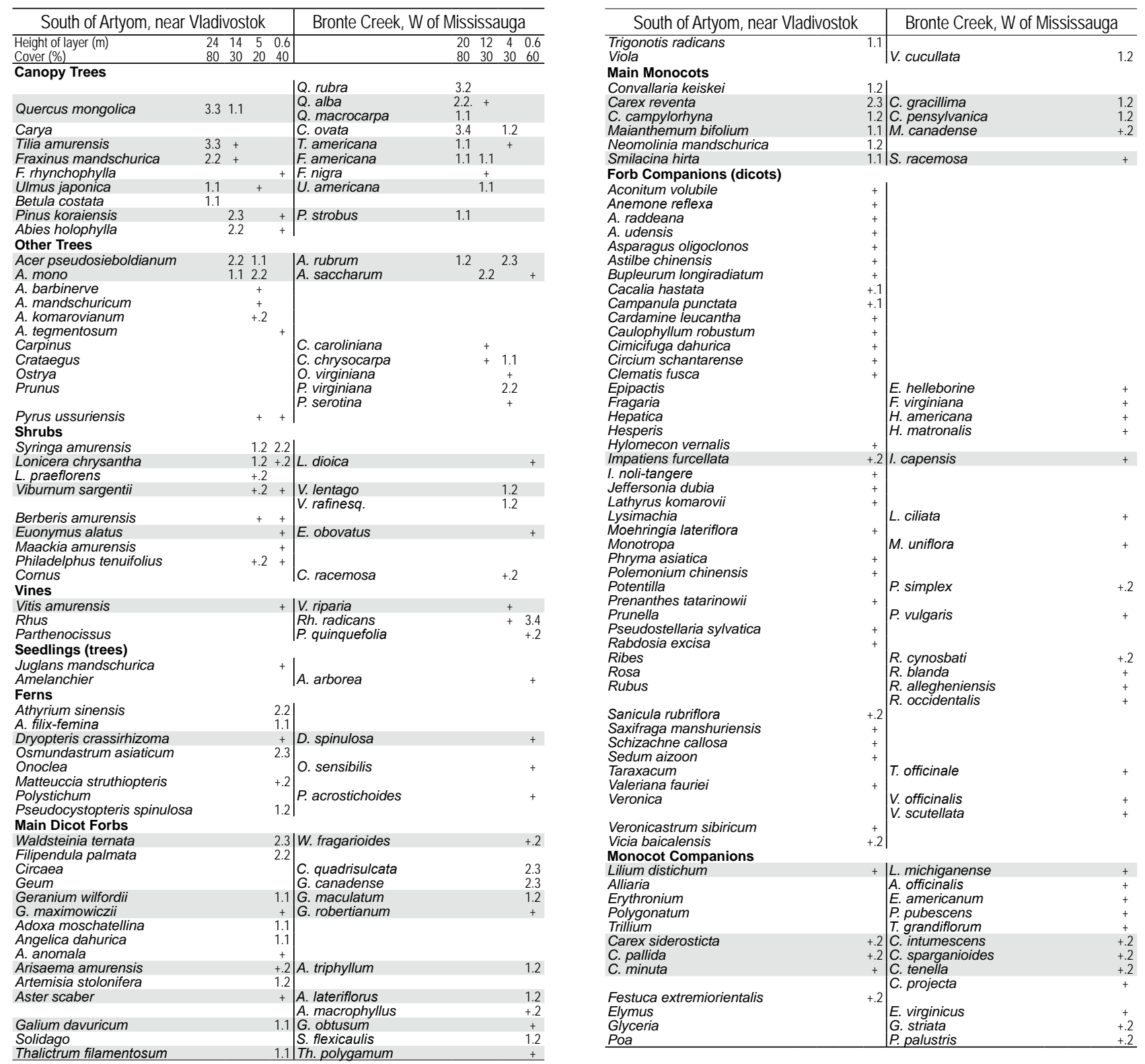

Both forest stands were at about $43^{\circ} \mathrm{N}$ latitude, in regions of cool-temperate humid climate. The Primorye stand was on the peninsula south of Artyom, east of Vladivostok, on mesic-moist soil. The Bronte Creek stand was on mesic, undulating terrain west of Mississauga (just west of Toronto), in southern Ontario. Both relevés covered about $400 \mathrm{~m}^{2}$ in area. Juxtaposition of species on the same line does not imply vicariance, only that the species are congeneric. Beyond the presence of significant amounts of Pinus koraiensis (East Asia) or Pinus strobus (eastern N America), these stands were not selected for their similarity; they were in fact the only such samples in our data-bases for these regions. Species names follow local usage at the time of data collection. Shaded cells represent species in the same genus that are relatively similar.

Another important need is for a common zonation vocabulary. The comment above about the Russian 'continental' sector suggests that this sector might better be called 'ultracontinental', in order not to conflict with more global usage. The ultra-continental sector is characterized by the lack of a transitional mixed-forest zone, since the temperate forest zone is truncated abruptly by the appearance of permafrost (item 2). More problematic is the official Chinese zonation system, which in some terms is in direct conflict with more global usage. Since the prefix 'sub' means almost, one expects that regions called 'sub' (e.g. subtropical) should be transitional and smaller than main regions (e.g. tropical, temperate and polar). Some temperate deciduous forests in southern Japan were recognized by Kira as 'warm-temperate deciduous forests', and this description also seems to fit significant areas of 'thermophilous' deciduous forest in southern Europe and of (deciduous) 'southern hardwood' forests in the southeastern USA. This description also seems to fit some deciduous forests in northern China - but not the whole deciduous forest region. Temperate deciduous forests are the zonal vegetation of the typical-temperate climatic zone. The term 'warm-temperate' is applied better to the zone of evergreen broad-leaved forests that are composed still of mainly temperate-zone taxa.

A third main need is for a focus on just what constitutes a species in East Asia, with its many local subspecies and varieties, some of which are now being elevated to species status for reasons that are not always clear. 
- What makes congeneric species different? They should be different not just in subtle aspects of morphology, or even reproductive timing, but also in their ecology.

- Are their environmental (e.g. climatic) spaces and requirements different and how?

-What are the factors and histories that caused different congeneric species to evolve to be "different"?

- What vicariant species exist in other, comparable areas?

All of the above perhaps also provides an opportunity to try to synthesize our knowledge of limiting factors, both for taxa and vegetation types, and to test whether the same limiting values appear to apply across the whole region and perhaps also on other continents.

Finally, there is also a need for more and better climatic data in some areas. Despite the great number of meteorological stations in both Russia and China, the network is sparse because the countries are so large. There is, however, a worse problem. In complex terrain, including river valleys as well as mountainous areas, cold air "drains" into and collects in low areas, which is where almost all the meteorological stations are located. Climatic conditions on middle and upper mountain slopes, and even on the broad uplands between the large Siberian river valleys, must thus be estimated, based on the data from the lower, colder stations. Some good attempts are being made, especially in China, to estimate temperature lapse rates and even rates of precipitation change in mountain areas, not only as single figures but as different values for different sides of mountains (see Leigong-Shan Committee 1989). This problem of effective climatic conditions in complex topography is well known, but perhaps one final example will illustrate how extreme the problem can be.

In 2006 we were studying the forest vegetation at about $1800 \mathrm{~m}$ in the Xiaolongshan $\left(34.37^{\circ} \mathrm{N}, 106.21^{\circ} \mathrm{E}\right)$, above Tianshui, located at about $1175 \mathrm{~m}$ in the Wei river valley in southeastern Gansu Province (China). Mean monthly temperature and precipitation for Tianshui, the closest nearby meteorological station $\left(34.58^{\circ} \mathrm{N}, 105.75^{\circ} \mathrm{E}\right)$, measured over the years 1935-1988, were as follow:

Jan Feb Mar Apr May Jun Jul Aug Sep Oct Nov Dec

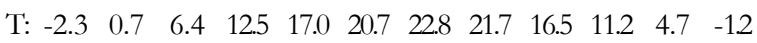

$\begin{array}{lllllllllllll}\text { P: } & 4 & 6 & 16 & 40 & 58 & 74 & 92 & 93 & 91 & 42 & 14 & 3\end{array}$

Mean annual temperature was $10.9^{\circ} \mathrm{C}$, and mean minimum temperature in January was estimated as $7.6^{\circ} \mathrm{C}$; average annual precipitation was $533 \mathrm{~mm}$. There are two months with mean temperature below $0^{\circ} \mathrm{C}$, and the absolute minimum temperature, based on relevant lapse rates (for which data are available by month in China), was estimated as about $-17.5^{\circ} \mathrm{C}$. According to the normal rule of thumb (see Table 6 ), this temperature below $-15^{\circ} \mathrm{C}$, even of short duration, would preclude evergreen broadleaved woody plants, even when adequate water is available.

Temperatures and precipitation at the study site $(1870 \mathrm{~m})$ were extrapolated from the valley data, using the same lapse rates $\left(5.5-6.0^{\circ} \mathrm{C} / 1000 \mathrm{~m}\right)$, yielding a mean annual temperature of $7.1^{\circ} \mathrm{C}$, mean minimum of about $-11^{\circ} \mathrm{C}$, and an absolute minimum of $21.3^{\circ} \mathrm{C}$, with average annual precipitation of $695 \mathrm{~mm}$. The estimated mean monthly values are as follow:
Jan Feb Mar Apr May Jun Jul Aug Sep Oct Nov Dec T: $\begin{array}{lllllllllllll}6.1 & -3.1 & 2.6 & 8.7 & 13.2 & 16.9 & 19.0 & 17.9 & 12.7 & 7.4 & 0.9 & -5.0\end{array}$

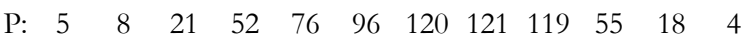

This means that at least three months would have means below $0^{\circ} \mathrm{C}$. These extrapolated values would be wrong, of course, because temperature actually increases upward until one gets above the inversion layer. Even with allowances for this, though, mean winter temperatures at $1800 \mathrm{~m}$ would probably still be estimated as below $0^{\circ} \mathrm{C}$, which would be too cold for evergreen broad-leaved trees.

Since the water balance was much ameliorated on the upper slopes, the forest at our study site was dominated by summergreen deciduous Quercus species, mainly, Q. liaotungensis and Q. aliena. Growing among them, however, was also a moderately large oak tree with leaves that, in comparison with the other oaks around, were clearly:

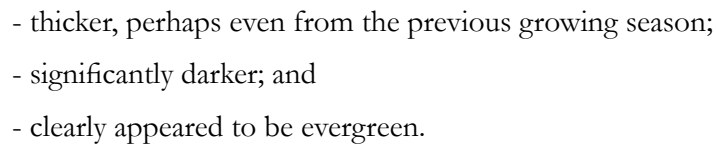

The occurrence of even one evergreen oak generally means that the rest of a [deciduous] forest is secondary. In fact the evergreen oak was identified as Quercus spinosa, which according to the "Flora of China" (Wu \& Raven 1999, v. 4) ranges naturally from Jiangxi and Fujian to Yunnan, and occurs in Taiwan and Tibet. How could it survive there, at such low winter temperatures? If one includes an inversion layer of expectable depth, one could estimate temperatures might not contradict the presence of an evergreen broad-leaved tree but how many climate models do this?

We cannot answer this puzzle because we will never have the opportunity to return to that location in winter to measure the temperatures, even for short durations. This paradox has direct, significant implications, however, for vegetationclimate studies in complex terrain. So we encourage our Chinese colleagues to make the relevant winter temperature measurements and to share them with us. We also hope that modelers will take note, especially those with less field experience.

\section{ACKNOWLEDGEMENTS}

The greatest thanks goes to Pavel Krestov for supplying some of the species range maps, some additional site climatic data, and for organizing and leading our fieldwork in various parts of the Russian Far East in 2003, 2006 and 2007. Many thanks also to Valentin Yakubov (Vladivostok), Sergey Zimov and Sergey Davydov (Cherskiy), and Evgeniy Nikolin (Yakutsk) for taxonomic assistance during this fieldwork. Finally, thanks also to Robert Liebermann (University of Georgia) for providing bound, printed scans of the Hultén range maps. Travel expenses were supported by a grant from the Japanese Society for Promoting of Science (JSPS) to the second author. 


\section{LITERATURE CITED}

Alekhin, V. V. 1951. Vegetation of the USSR in its fundamental zonation. 2nd ed. Sovetskaya Nauka, Moscow. 512 pp. + map (in Russian). [Алехин В. В. 1951. Растительность СССР в основных зонах. 2-е изА. Москва: Советская наука. 512 с. + карта.]

Anonymous 1966-1971. Reference book on the climate of the USSR Series of volumes. Gidrometeoizdat, Leningrad (in Russian). [Справочник по климату СССР. 1966-1971. Аенинград: ГиАрометеоизАат.]

Arakawa, H. (ed.) 1969. Climates of northern and eastern Asia. In: World survey of climatology, vol. 8. (H. Landsberg, ed.), pp. 1-248. Elsevier, Amsterdam.

Archibold, O. W. 1995. Ecology of world vegetation. Chapman and Hall, London. 510 pp.

Arris, L. L. \& P. S. Eagleson 1989. Evidence of a physiological basis for the boreal-deciduous forest ecotone in North America. Vegetatio 82:55-58.

Barbour, M. G. \& W. D. Billings (eds.) 1988. North American terrestrial vegetation. Cambridge University Press, Cambridge. 434 pp.

Boufford, D. E. \& S. A. Spongberg 1983. Eastern Asian - eastern North American phytogeographical relationships: a history from the time of Linnaeus to the twentieth Century. Annals of Missouri Botanical Garden 70(3):423-439.

Box, E. O. 1981. Macroclimate and plant forms: an introduction to predictive modeling in phytogeography. Tasks for vegetation science, vol. 1. Dr. W. Junk BV, The Hague. 258 pp.

Box, E. O. 1995a. Factors determining distributions of tree species and plant functional types. Vegetatio 121:101-116.

Box, E. O. 1995b. Climatic relationships of the forests of east and Southeast Asia. In: Vegetation science in forestry: global perspective based on forests ecosystems of East and Southeast Asia (E. O. Box et al., eds.), pp. 23-55, Kluwer Academic Publishers, Dordrecht.

Box, E. O. 1995c. Global potential natural vegetation: dynamic benchmark in the era of disruption. In: Toward global planning of sustainable use of the Earth - development of global eco-engineering (Sh. Murai, ed.), pp. 77-95. Elsevier, Amsterdam.

Box, E. O. 2002. Vegetation analogs and differences in the Northern and Southern Hemispheres: a global comparison. Plant Ecology 163:139-154.

Box, E. O. \& J. N. Choi 2003. Climate of Northeast Asia. In: Forest vegetation of Northeast Asia (J. Kolbek. et al., eds.), pp. 5-31. Kluwer Academic Publishers, Dordrecht.

Box, E. O., D. W. Crumpacker \& E. D. Hardin 1993. A climatic model for location of plant species in Florida, USA. Journal of Biogeography 20:629-644.

Box, E. O. \& K. Fujiwara 2004. Vegetation types and their broadscale distribution. In: Vegetation É cology (E. van der Maarel, ed.), pp. 106-128. Blackwell, Oxford.

Box, E. O. \& K. Fujiwara 2010. What else can one do with relevé data: Eastern North America? Braun-Blanquetia 46:139-142.

Box, E. O. \& K. Fujiwara 2011. Sorting plots not taxa for studying plant species richness. Plant Biosystems 145:46-53.

Box, E. O. \& M. Manthey 2006. Conservation of deciduous tree species in Europe: projecting potential ranges and changes. In: Nature conservation: concepts and practice (D. Gafta \& J. Akeroyd, eds.), pp. 241253. Springer-Verlag, Berlin.

Box, E. O., You H.-M. \& Li D.-L. 2001. Climatic ultra-continentality and the abrupt boreal-nemoral forest boundary in northern Manchuria. In: Studies on the vegetation of alluvial plains (Assn. commemorate retirement of prof. Okuda), pp. 183-200. Yokohama.

Box, E. O. (ed.), R. K. Peet, T. Masuzawa, I. Yamada, K. Fujiwara \& P. F. Maycock (co-eds.) 1995. Vegetation science in forestry: global perspective based on forest ecosystems of east and southeast Asia. Handbook vegetation science, vol. 12/1. Kluwer Academic Publishers, Dordrecht. 663 pp.

Braun, E. L. 1950. Deciduous forests of eastern North America. Blakiston Co., Philadelphia. 596 pp.

Cao, K.-F. \& R. Peters 1997. Species diversity of Chinese beech forests in relation to warmth and climatic disturbance. Ecological Research (Japan) 12:175-189.
Chen, L.-Zh. 1986. The oak forest in North China. In: Proceedings of international symposium on mountain vegetation (Chen L.-Zh. \& Chang Hs.-Sh., eds.), pp. 203-208. Bot. Soc. China, Beijing.

Chen, L.-Zh. 1995a. Deciduous broad-leaved forests in north-central China. In: Vegetation science in forestry (E.O. Box et al., eds.), pp. 255-271.Kluwer Academic Publishers, Dordrecht.

Chen, L.-Zh. 1995b. The spruce forests of Northern China. Ibid., pp. 353-365.

Chen, L.-Zh. \& S. Pignatti (eds.) 1992. Mountain vegetation (Proceedings of international symposium, Beijing, Sept. 1986). Braun-Blanquetia 8:1-227.

Chen, W.-L. 1995. Subtropical montane deciduous forests in Southern China. In: Vegetation science in forestry (E. O. Box et al., eds.), pp. 317-323. Kluwer Academic Publishers, Dordrecht.

China natural geography editorial commission (eds.) 1984. China natural geography: climate. Science Press, Beijing. 161 pp. (in Chinese).

Chou (= Zhou), Yi-L. \& Liu, J.-W. 1995. Deciduous and deciduous-evergreen forests in northeastern China. In: Vegetation science in forestry (E. O. Box et al., eds.), pp. 307-315. Kluwer Academic Publishers, Dordrecht.

Ermakov, N., D. Julian \& J. Rodwell 2000. Classification of continental hemi-boreal forests of north Asia. Braun-Blanquetia 28:1131.

Fu, L.-K. \& T.-Q. Chen (eds.) 1999. Higher Plants of China. Series of volumes. Qingdao Publishers (in Chinese).

Fujiwara, K. 1987. Aims and methods of phytosociology or "vegetation science". In: Papers on plant ecology and taxonomy to the memory of Dr. Satoshi Nakanishi (Y. Takeda, ed.), pp. 607-628. Kôbe Geobotanical Society, Kôbe.

Fujiwara, K. (project leader) 2008. Integrated vegetation mapping of Asia. Report to Japan society for promotion of science, $189 \mathrm{pp}$.

Fujiwara, K., H.-M. You, Q. Tang, A. Harada, Zh.-X. Wang \& L. Wang 2008. Deciduous Quercus and Fagus forests in Asia. In: Integrated vegetation mapping of Asia. Report to Japan society for promotion of science, project \#16255003 (K. Fujiwara, project leader), pp. 111-129.

George, M. F., M. J. Burke, H. M. Pellett \& A. G. Johnson 1974. Low-temperature exotherms and woody plant distribution. Hort Science 9:519-522.

Graham, A. (ed.) 1972. Floristics and paleofloristics of Asia and eastern North America. Elsevier, Amsterdam. 278 pp.

Gray, A. 1846. Analogy between the flora of Japan and that of the United States. American Journal of Science and Arts 2(2):135-136.

Gray, A. 1859. Observations upon the relationship of the Japanese flora to that of North America and other parts of the northern hemisphere. Memoirs of the American Academy of Arts and Sciences 6:377-453.

Greller, A. M. 1989. Correlation of warmth and temperateness with the distributional limits of zonal forests in eastern North America. Bulletin of the Torrey Botanical Club 116:145-163.

Grishin, S. Y. 1995. The boreal forests of northeastern Eurasia. Vegetatio 121:11-21.

Hämet-Ahti, L., T. Ahti \& T. Konen 1974. A scheme of vegetation zones for Japan and adjacent regions. Annales Botanici Fennici 11:59-88.

Hara, H. (ed.) 1959. Distribution maps of flowering plants in Japan. 2 vols, with 200 maps by H. Hara and H. Kanai. Inoue Books, Tokyo.

Hayashi, Y. 1985. Woody plants of Japan [Nibon-no Jumoku]. YamaKei, Tokyo, 751 pp. (in Japanese, with Latin Index).

Horikawa, Y. 1972, 1976. Atlas of Japanese flora, an introduction to plant sociology of East Asia. 2 vols. Gakken, Tokyo, 500 pp. +7 pp. index; 862 pp. +11 pp. index.

Hou, X.-Yu 1983. Vegetation of China with reference to its geographical distribution. Annals of the Missouri Botanical Garden 70:509-548.

Hou, X.-Yu et al. (eds.) 1979. Vegetation map of China. Institute of Botany (Academia Sinica) and Map Press, Beijing, Map $(1: 4,000,000$, in Chinese) + separate legend (Chinese and English, 12 pp); 2nd edition 1982. 
Hukusima, T., H. Takasuna, T. Matsui, T. Nishio, Y. Kyan \& Y. Tsunetomi 1995. New phyto-sociological classification of beech forests in Japan. Japanese Journal of Ecology 45:79-98 (in Japanese; English abstract).

Hultén, E. \& M. Fries 1986. Atlas of North European Vascular Plants. 3 vols. Koelz Scientific, Königstein. 1149 pp.

Institute of Botany 1972-1985. Iconographia cormophytorum sinicorum [Zhongguo gaodeng Zhiwu tujian]. 5 vols. Academia Sinica. Science Press, Beijing (in Chinese, with Latin indices).

Kharkevich, S. S. (ed.) 1985-1996. The vascular plants of the Soviet Far East, vol. 1-8. Nauka, Leningrad (in Russian). [Сосудистые растения советского Аальнего Востока / под реА. С.С. Харкевича. 1985-1996. Аенинград: Наука. Т. 1-8.]

Kim, J.-W. 1990. A syntaxonomic scheme for the deciduous oak forest of South Korea. Abstracta Botanica 14:51-81.

Kira, T. 1945. A new classification of climate in eastern Asia, as the basis for agricultural geography. Horticultural Institute, University, Kyoto, 23 pp. (in Japanese).

Kira, T. 1949. Forest zones in Japan. Ringyō Kaisetsu (Nippon Ringyō Gijutsu Kyōkai) 17:105-141 (in Japanese).

Kira, T. 1977. A climatological interpretation of Japanese vegetation zones. In: Vegetation science and environmental protection (A. Miyawaki, ed.), pp. 21-30. Maruzen, Tokyo.

Kira, T. 1991. Forest ecosystems of East and Southeast Asia in a global perspective. Ecological Research (Japan) 6:185-200.

Kolbek, J., M. Šruitek \& E. O. Box (eds.) 2003a. Forest vegetation of Northeast Asia. Kluwer Academic Publishers, Dordrecht. 462 pp.

Kolbek, J., I. Jarolimek \& M. Valachović 2003b. Forest vegetation of the Northern Korean Peninsula. In: Forest vegetation of Northeast Asia. (J. Kolbek et al., eds.), pp. 263-361. Kluwer Academic Publishers, Dordrecht.

Krasnoborov, I. M. (ed.) 1988-1997. Flora of Siberia, vol. 1-14. Nauka, Novosobirsk (in Russian). [ФАора Сибири / под. реА. И. М. Красноборова 1988-1997. Новосибирск: Наука. Т. $1-14$.

Krestov, P. 2003. Forest Vegetation of Easternmost Russia (Russian Far East). In: Forest vegetation of Northeast Asia (J. Kolbek et al., eds.), pp. 93-180. Kluwer Academic Publishers, Dordrecht.

Krestov, P. V., N. B. Ermakov, S. V. Osipov \& Y. Nakamura 2010. Classification and phytogeography of larch forests of northeast Asia. Folia Geobotanica 44(4):323-363.

Krestov, P. V. \& Y. Nakamura 2002. Phytosociological study of the Picea jezoensis forests of the Far East. Folia Geobotanica 37:441473.

Krestov, P. V. \& Y. Nakamura 2007. Climatic controls of forest vegetation distribution in Northeast Asia. Berichte der ReinholdTüxen-Gesellschaft 19:131-145.

Krestov, P. V., J.-S. Song, Y. Nakamura \& V. P. Verkholat 2006. A phytosociological survey of the deciduous temperate forests of mainland Northeast Asia. Phytocoenologia 36(1):77-150.

Larcher, W. 1954. Die Kälteresistenz mediterraner Immergrüner und ihre Beeinflußbarkeit. Planta 44:607-638.

Larcher, W. 1973. Ökologie der Pflanzen. Uni-Taschenbücher 232. Eugen Ulmer, Stuttgart. 320 pp.

Larcher, W. 2005. Climatic constraints drive the evolution of lowtemperature resistance in woody plants. Journal of Agricultural Meteorology (Japan) 61(4):189-202.

Leigong-Shan committee 1989. Scientific survey of Leigongshan mountain nature reserve. Guizhou People's Press, Guiyang, pp. 77-79 (in Chinese).

Lusk, Ch. 2008. Constraints on the evolution and geographical range of Pinus. New Phytologist 178:1-3.

Lydolph, P. E. 1977. Climates of the Soviet Union. In: World survey of climatology, vol. 7 (H. Landsberg, ed.), pp. 1-443. Elsevier, Amsterdam.

Manthey, M. \& E. O. Box 2007. Realized climatic niches of deciduous trees: comparing western Eurasia and eastern North America. Journal of Biogeography 34:1028-1040.

Menitsky, Y. L. 2005. Oaks of Asia. Science Publishers, Enfield, NH \& Plymouth, UK. 549 pp.
Miller, H. \& S. Lamb 1985. Oaks of North America. Naturegraph, Happy Camp (California). $327 \mathrm{pp}$.

Miyawaki, A., K. Iwatsuki \& M. M. Grandtner (eds.) 1994. Vegetation in eastern North America. Tokyo University Press, Tokyo. 515 pp.

Miyawaki, A. (ed.) 1980-1989. Japan Vegetation Record [Nihon Shokusei Shi], 10 vols. Shibundo, Tokyo (in Japanese; with German, English summaries).

Nakai, T. 1938. East Asian Plants [Tö-A no shokubutsu]. IwanamiShoten, Tokyo. 283 pp. +87 pp. indices (in Japanese).

Nakamura, Y., P. V. Krestov \& A. M. Omelko 2007. Bioclimate and zonal vegetation in Northeast Asia: first approximation to an integrated study. Phytocoenologia 37(3-4):443-470.

Numata, M. (ed.) 1974. The flora and vegetation of Japan. Kodansha, Tokyo \& Elsevier, Amsterdam. 294 pp.

Numata, M., A. Miyawaki \& D. Itow 1972. Natural and seminatural vegetation in Japan. Blumea 20:435-481.

Okitsu, S. 2003. Forest vegetation of Northern Japan and the Southern Kurils. In: Forest vegetation of Northeast Asia. (J. Kolbek et al., eds.), pp. 231-261. Kluwer Academic Publishers, Dordrecht.

Peters, R. 1997. Beech forests. Kluwer Academic Publishers, Dordrecht. $169 \mathrm{pp}$.

Physical regionalization committee. 1958-1959. General natural divisions of Cbina. Science Press, Beijing (in Chinese).

Qian, H., X.-Y. Yuan \& Yi-L. Chou 2003. Forest vegetation of Northeast China. In: Forest vegetation of Northeast Asia (J. Kolbek et al., eds.), pp. 181-230. Kluwer Academic Publishers, Dordrecht.

Qian, H., P. S. White \& J.-S. Song 2007. Effects of regional vs ecological factors on plant species richness: an intercontinental analysis. Ecology 88(6):1440-1453.

Quarterman, E. \& Ch. Keever 1962. Southern mixed hardwood forest: climax in the southeastern coastal plain, USA. Ecological Monographs 32:167-185.

Sakai, A. 1971. Frost hardiness of evergreen and deciduous broadleaved trees native to Japan. Low-temperature science (Japan), ser. B 35:15-43 (in Japanese, with English summary).

Sakai, A. \& W. Larcher 1987. Frost survival of plants: responses and adaptation to freezing stress. Springer-Verlag, Berlin. $321 \mathrm{pp}$.

Shimano, K. 1999. The effects of snow upon Japan Sea-type beech forests. Journal of Phytogeography and Taxonomy 47:97-106 (in Japanese, with English abstract).

Song, Y.-Ch. 1983. Die räumliche Ordnung der Vegetation Chinas. Tüxenia 3:131-157.

Suslov, S. P. 1961. Physical geography of Asiatic Russia. W. H. Freeman, San Francisco. 594 pp.

Suzuki, T. 1952. Forest vegetation of East Asia [Tou-A no Shin-Rin Shokusei]. Kokon Shôin, Tokyo. 137 pp. (in Japanese).

Suzuki, T. 1953. The forest climaxes of East Asia. Japanese Journal of Botany 14:112.

Taneda, H. \& J. S. Sperry 2008. A case study of water transport in co-occurring ring- versus diffuse-porous trees: contrasts in water status, conducting capacity, cavitation and vessel refilling. Tree Physiology 28:1641-1651.

Tang, Q., K. Fujiwara \& H.-M. You 2008. Warm-temperate deciduous Quercus forest in China. In: Integrated vegetation mapping of Asia. Report to Japan society for promotion of science (K. Fujiwara, project leader), pp. 102-110.

Troll, C. 1961. Klima und Pflanzenkleid der Erde, in dreidimensionaler Sicht. Die Naturwissenschaften 48:332-348.

Troll, C. \& K. H. Paffen 1964. Karte der Jahreszeitenklimate der Erde. Erdkunde, Arch. Wiss. Geogr. 18:5-28.

Tuhkanen, S. 1984. A circumboreal system of climatic-phytogeographical regions. Acta Botanica Fennica 127:150.

Walter, H. 1970. Vegetation und Klimazonen. Uni-Taschenbücher. Verlag Eugen Ulmer, Stuttgart. 382 pp.

Walter, H. 1974. Die Vegetation Osteuropas, Nord- und Zentralasiens. Vegetation der Einzelnen Grossräume. Gustav-Fischer-Verlag, Stuttgart. $452 \mathrm{pp}$. 


\section{Elgene O. Box \& Kazue FUJIWARA}

Walter, H. 1979. Vegetation of the Earth and ecological systems of the geobiosphere. 2nd edition. SpringerVerlag, New York. 274 pp.

Walter, H. \& E.O. Box 1976. Global classification of natural terrestrial ecosystems. Vegetatio 32:75-81.

Wang, C.-W. 1961. The forests of China, with a survey of grassland and desert vegetation. Maria Moors Cabot Foundation Publ. no. 5. Harvard University, Cambridge. 313 pp.

Wang, L., K. Fujiwara \& H.-M. You 2006. A vegetation-ecological study of deciduous broad-leaved forests in Heilongiang Province, China: species composition, structure, distribution and phytosociological scheme. Hikobia 14:431-457.

Wang, Zh.-X. \& K. Fujiwara 2003. A preliminary vegetation study of Fagus forests in central China: species composition, structure and ecotypes. Journal of Phytogeography and Taxonomy 51:137-157.

Wang, Zh.-X., K. Fujiwara \& Y. Lei 2005. Phytosociological study of the Fagus lucida forests and Fagus engleriana forests in China. Journal of Phytogeography and Taxonomy 53:43-65.

Wolfe, J. A. 1979. Temperature parameters of bumid to mesic forests of eastern Asia and relation to forests of other regions of the Northern Hemisphere and Australasia. U.S. Geological Survey (Washington), Professional Paper No. 1106. 37 pp.

Woodcock, D. W. 1994. Occurrence of woods with a gradation in vessel diameter across a ring. IAWA Journal 15(4):377-385.

Woodward, I. 1987. Climate and plant distribution. Cambridge University Press, Cambridge. 174 pp.

Wu, Zh.-Yi \& Committee (eds.) 1980, 1995. Vegetation of China [Zhongguo Zhibei]. Science Press, Beijing, 1375 pp. + 339 B/W photos; 1382 pp. + photos (in Chinese; Latin-Chinese species lists).

Wu, Zh.-Yi \& P. H. Raven (eds.) 1999. Flora of China, vol. 4. Science Press, Beijing. 374 pp.

Xu, W.-D. 1986. The relation between the zonal distribution of types in northeast China. Acta Phytoecologica et Geobotanica Sinica 10(4):254-263 (in Chinese).

Yagihashi, T., T. Matsui, T. Nakaya, N. Tanaka \& H. Taoda 2007. Climatic determinants of the northern range limit of Fagus crenata forests in Japan. Plant Species Biology 22:217-225.

Yim, Y.-J. 1977. Distribution of forest vegetation and climate in the Korean Peninsula. Parts 3 and 4. Japanese Journal of Ecology 27:177-189, 269-278.
Yim, Y.-J. 1995. Composition and distribution of deciduous broad-leaved forests in Korea. In: Vegetation science in forestry (E.O. Box et al., eds.), pp. 273-298. Kluwer Academic Publishers, Dordrecht.

Yim, Y.-J. \& T. Kira 1975-1976. Distribution of forest vegetation and climate in the Korean Peninsula. Parts 1 and 2. Japanese Journal of Ecology 25:77-88, 26:157-164.

You, H.-M., K. Fujiwara, S.-J. Wu \& X.-L. Wang 2001. A preliminary vegetation-ecological study of Quercus mongolica forests in China. Journal of Phytogeography and Taxonomy 49:31-51.

You, H.-M. \& K. Fujiwara 2008. Quercus liaotungensis forest in China. In: Integrated vegetation mapping of Asia. Report to Japan society for promotion of science (K. Fujiwara, project leader), pp. 91-101.

Zhang, F.-G. 2000. Community characteristics of the Taiwan beech forest of Qingliangfeng Mountain in Zhejiang. Journal of Zhejiang University (Agric \& Life Science) 27(4):403-406 (in Chinese).

Zhao, S.-Q. 1986. Physical Geography of China. Science Press, Beijing, 209 pp. +64 color photos and 11 Landsat images.

Zhao, Y.-Zh. \& H. Tian 2001. Taxonomic revision and floristic analysis of Quercus in Inner Mongolia. Inner Mongolia University Study Reports 32(4):470-472 (in Chinese).

Zhi-Rong, K. Fujiwara, K. Ohno \& Y.-Zh. Zhao 2010. Phytosociological study of the Ouercus mongolica forests in the Da Xingan Ling, China. Eco-Habitat: JISE Research 17(1):59-79 (in Japanese).

Zhou, Yi-L. (ed.) 1986. Ligneous flora of Heilongjiang [Heilongjiang Shumu Zhi]. Heilongjiang Science Press, Harbin. 585 pp. (in Chinese).

Zhou, Yi-L. (ed.) 1991. Vegetation of the Da Hinggan Ling in China [Zhongguo Da Xingan Ling Zhibei]. Science Press, Beijing. 264 pp. (in Chinese).

Zhou, Yi-L. \& Y.-G. Zu (eds.) 1997. Geography of the vegetation in Northeast China [Zhongguo Dongbei Zhibei Dili]. Science Press, Beijing. 446 pp. (in Chinese).

Zhu, S.-Q. \& Y.-Q. Yang 1985. Structure and dynamics of Fagus lucida forest of Guizhou Province. Acta Phytoecologica et Geobotanica Sinica 9(3):183-191 (in Chinese, with English abstract). 
